\title{
19 May 2011 Kütahya - Simav earthquake and evaluation of existing sample RC buildings according to the TEC-2007 criteria
}

\author{
M. H. Arslan ${ }^{1}$, M. Olgun ${ }^{1}$, M. A. Köroğlu ${ }^{2}$, I. H. Erkan ${ }^{1}$, A. Köken ${ }^{1}$, and O. Tan ${ }^{1}$ \\ ${ }^{1}$ Department of Civil Engineering, Selcuk University, 42075 Konya, Turkey \\ ${ }^{2}$ Department of Civil Engineering, Necmettin Erbakan University, 42060 Konya, Turkey \\ Correspondence to: M. H. Arslan (mharslan@ selcuk.edu.tr) \\ Received: 19 October 2012 - Published in Nat. Hazards Earth Syst. Sci. Discuss.: - \\ Revised: 25 December 2012 - Accepted: 3 January 2013 - Published: 25 February 2013
}

\begin{abstract}
This study examines the damage caused to reinforced concrete structures by the 2011 earthquake that occurred in Simav, Turkey. The study briefly reports on postearthquake field observations, tectonic characteristics of the earthquake area, geotechnical characteristics of the field, and seismic characteristics of the earthquake. The main part of the study comprises a field study, material experiments, and performance analyses of two reinforced concrete buildings that survived the earthquake with medium level damage. The building performance was calculated and assessed according to the Turkish Earthquake Code requirements for existing building stock, and recommendations were made based on the findings.
\end{abstract}

\section{Introduction}

Turkey is situated in an active earthquake zone and more than $90 \%$ of its land area is within highly seismic regions. During the 20th century, Turkey experienced several moderate to heavy earthquakes that resulted in significant loss of life and property, and 22 major earthquakes with minimum magnitudes $7\left(M_{\mathrm{w}}\right)$ caused significant casualties and extensive structural damage (Arslan and Korkmaz, 2007; Çağatay, 2005; Inel et al., 2008). The literature includes many studies of earthquakes and post-earthquake case studies in Turkey because several destructive earthquakes have hit the country during the last two decades (including 1992 Erzincan $\left(M_{\mathrm{w}}=6.8\right), 1996$ Adana-Ceyhan $\left(M_{\mathrm{w}}=6.3\right), 1999$ Adapazari-Izmit $\left(M_{\mathrm{w}}=7.4\right), 1999$ Düzce $\left(M_{\mathrm{w}}=7.2\right), 2002$ Afyon-Sultandagi $\left(M_{\mathrm{w}}=6.5\right), 2003$ Bingol $\left(M_{\mathrm{w}}=6.4\right), 2010$ Elazı $\breve{g}\left(M_{\mathrm{w}}=6.0\right), 2011 \operatorname{Van}\left(M_{\mathrm{w}}=\right.$
7.2)) (Arslan and Korkmaz, 2007; Çağatay, 2005; Inel et al., 2008; Tan et al., 2008; Adalier and Aydıngün, 2001; Sezen et al., 2003; Doğangün, 2004; Celep et al., 2011; Kaplan et al., 2004). The majority of these studies are related to buildings with reinforced concrete (RC) structural systems. However, most of the low-rise residential buildings constructed in villages and small towns are masonry structures. Therefore, much of the knowledge about Turkish earthquake hazards, structural deficiencies, and errors are concentrated on RC and masonry structures (Arslan and Korkmaz, 2007; Çağatay, 2005; Inel et al., 2008; Kaltakc1 et al., 2007; Tan et al., 2008; Adalier and Aydıngün, 2001; Sezen et al., 2003; Doğangün, 2004; Celep et al., 2011; Kaplan et al., 2004; Arslan, 2010).

On 19 May 2011 an earthquake with magnitude $\left(M_{\mathrm{w}}\right)$ 5.7 occurred in Simav, in Kütahya Province, located in the western part of Turkey. According to the Earthquake Department of the Disaster and Emergency Management Presidency (DEMP), the earthquake occurred at 20:15 local time with epicenter coordinates of $39.1328^{\circ} \mathrm{N}, 29.0820^{\circ} \mathrm{E}$ at a depth of $24.46 \mathrm{~km}$. The earthquake resulted in 2 fatalities and more than 122 injuries. Approximately 2500 aftershocks occurred after the main shock (Sandıkkaya et al., 2011; İnel et al., 2011; Kaplan et al., 2011), with a magnitude range $\left(M_{\mathrm{L}}\right)$ of between 1.3 and 4.8 (Sandikkaya et al., 2011). After the earthquake Turkish researchers focused on understanding the causes of the damages on especially RC buildings. Tama (2012) investigated the buildings by P25-rapid assessment method. The method showed that two of the buildings were in "high risk band"; the other two fell into "detailed evaluation band", and the rest were in the "low risk band". So his findings demonstrated that the figure matched with the damages observed in the site survey after the earthquake. 


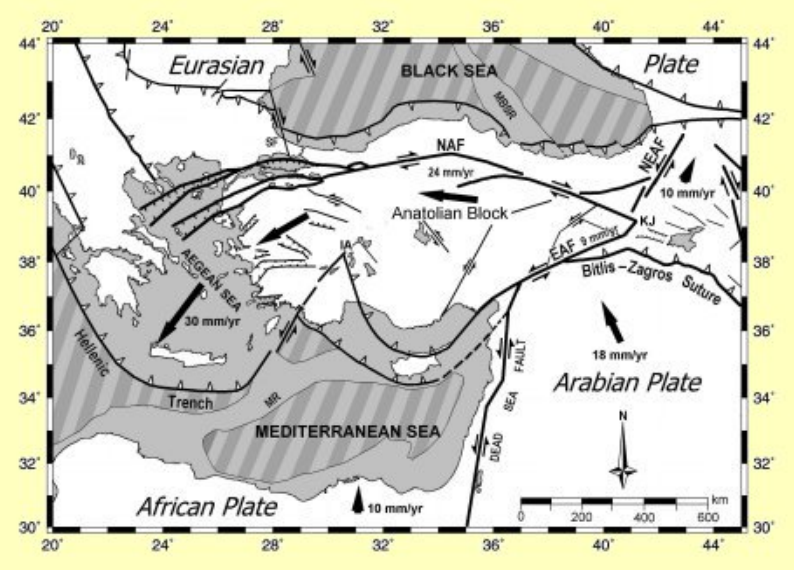

Fig. 1. Major tectonic elements and distribution in Turkey (Adalier and Aydingun, 2001).

This study briefly examined structural damage caused by this earthquake event. The seismic characteristics of the earthquake were determined by examining the seismic structure and soil features of the region. Soil and material experiments required by Turkish Earthquake Code (TEC-2007) norms were made in two low-rise buildings that experienced medium damage. Using the obtained data, the load systems of the buildings were evaluated to analyze structural performance. The main aim of the study is to compare two sample RC buildings located on alluvial soils, which suffered damage but remained standing, and to critically evaluate the provisions of the TEC-2007 regulations. For this purpose, the seismic performance of the selected buildings obtained by the non-linear evaluation procedures given in TEC-2007 has been conducted. Global performance of these buildings was determined from the member performances and the analytical results were compared with the experienced damage of the buildings. After the assessment a critical comparative evaluation has been done from the obtained results.

\section{Seismicity and geotechnical characteristics}

\subsection{Tectonic setting}

Turkey is located in the eastern Mediterranean segment on the Alpine-Himalayan earthquake belt and is frequently exposed to destructive earthquakes. According to the seismicity map of Turkey, $95 \%$ of the population and $92 \%$ of Turkish land is within seismically active areas (on seismic zones 1 to 4). The Kütahya-Simav region is in the first seismic zone according to the seismic zoning map of Turkey and has a seismic coefficient of $0.4 \mathrm{~g}$ according to TEC-2007.

There are seven major tectonic provinces in Turkey: the North Anatolian Fault (NAF), the Northeast Anatolian Fault (NEAF), the East Anatolian Contractional

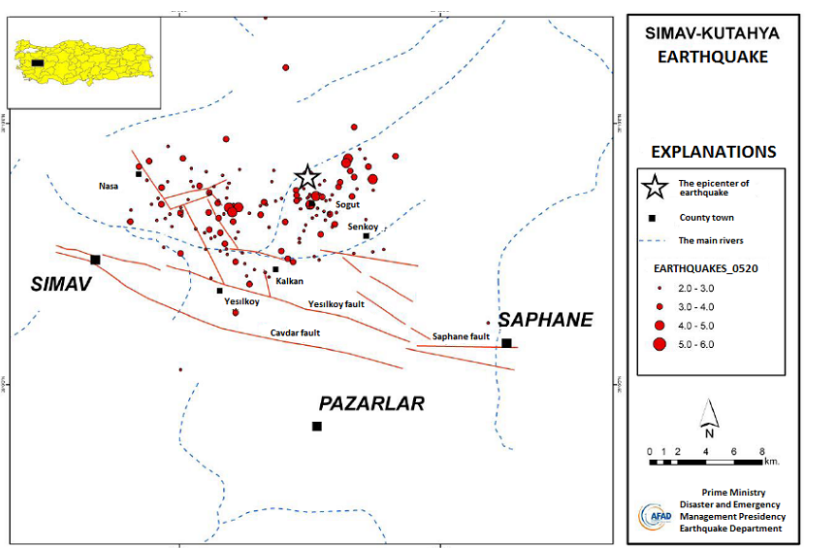

Fig. 2. Major faulting system in the Simav region (AFAD, 2011).

Province (EAF), the Aegean Graben System, the CyprusHellenic Arc, the Central Anatolian Province, and the Black Sea region (Sengor et al., 1985). The tectonics of Turkey is greatly influenced by the movements of the Arabian, Eurasian, and African plates (Fig. 1). The Arabian plate moves NE and pushes the Eurasian plate along the Bitlis thrust and fault zone. Due to this continuing movement of the Arabian plate, the Anatolian block shifts westward along the North and Northeast Anatolian faults. On the other hand, the African plate moves in the NE direction, colliding with the Eurasian plate, and subducts along the Cyprus-Hellenic Arc, somewhat retarding the westward movement of the Anatolian block and initiating its tendency to rotate to the SW. The interaction of these complex plate motions resulted in several E-W trending blocks bounded by oblique normal faults in southwest Turkey. Consequently, this region covering the Cyprus-Hellenic Arc and the Aegean Graben System has very high seismicity (Konak, 1982).

The Aegean region of Turkey, including Kütahya Province, is a highly active seismic area and has frequently been exposed to earthquakes. Kütahya is affected by the ground motions resulting from the Gediz-Emet, Simav, and Kütahya fault lines. Throughout history many destructive earthquakes causing loss of life and property have occurred in the region (Table 1). The highest magnitude earthquake recorded in this region was generated by the Gediz fault in March 1970 and resulted in more than 1000 casualties and the total collapse of 3500 buildings. The most recent disastrous earthquake of Kütahya-Simav in 2011, approximately $40 \mathrm{~km}$ from the epicenter of the 1970 Gediz earthquake, led to considerable damage in Simav, Kütahya.

Simav district is located within a collapsed basin (elevation $800 \mathrm{~m}$ ) known as the Simav Graben. Simav Mountain extends east-west and is located in the south of Simav. The most important tectonic feature of the study area is Simav Fault, an active right strike-slip fault extending approximately $205 \mathrm{~km}$ length in a general NW-SE direction 
Table 1. Recent destructive earthquakes in the Aegean region of Turkey.

\begin{tabular}{lll}
\hline Date & Instrumental Magnitude & Epicenter \\
\hline 1928 & 6.2 & Emet \\
1944 & 6.2 & Saphane \\
1970 & 7.2 & Gediz \\
1970 & 5.9 & Cavdarhisar \\
2011 & 5.7 & Simav \\
\hline
\end{tabular}

(Konak, 1982; Saroğlu et al., 1987, 1992). The epicenter of the 19 May 2011 Simav earthquake was the Simav Fault Zone. The region includes active fault segments within the Simav fault zone with a NW-SE direction (Fig. 2). Within the month following the earthquake, 1629 aftershocks occurred around the Simav epicenter. The magnitudes of most of these aftershocks (1322) were 3 or less $(\mathbf{M} \leq 3)$. The number of seismograms of the earthquakes whose magnitudes were between 3 and $4(3<M \leq 4)$ was 292 , and the number of seismograms of the ones between 4 and $5(4<M \leq 5)$ was 13 (Fig. 2).

\subsection{Geological setting}

The Kütahya-Simav region is characterized by plateaus of varying heights, with some mountains and hills as well as large plains. Both mountain and hill ranges and low areas are oriented in NW-SE direction, which is consistent with the general characteristics of the region. The Kütahya, Tavşanl, Altıntaş, Gediz, Simav, and Örencik plains, which are alluvium covered, form the lower parts of this region. The main part of the region consists of Neogene plateaus. Within the study region, the Neogene series begins with a thick conglomerate series and continues with clay, marl, and limestone series. Despite generally being horizontal, Neogene series are sometimes sloping. The region has many block faults as a result of these Neogene series. Tectonic activities are generally observed in the west and southwest of the region. Old Neogene terrestrial sediments are observed in the southeastern, northern, and northwestern parts of Simav district. In addition, pre-Neogene basic rock units of various ages can be found across a wide area. The land is generally rough except in the northern part of Simav and has many valleys of varying sizes. These valleys are generally filled with young alluvium carried by rivers.

The plain in the northern part of Simav district involves alluvial material with high groundwater level, and the southern part involves rock (limestone and schist) and slope wash materials (Fig. 3). Until 1960 Simav Lake extended northwest from Simav city center; after 1960, this lake was dried by opening channels, leaving black-dark grey organic clay. After drying the lake, the site was zoned for construction, and now includes a dense residential area and public buildings.

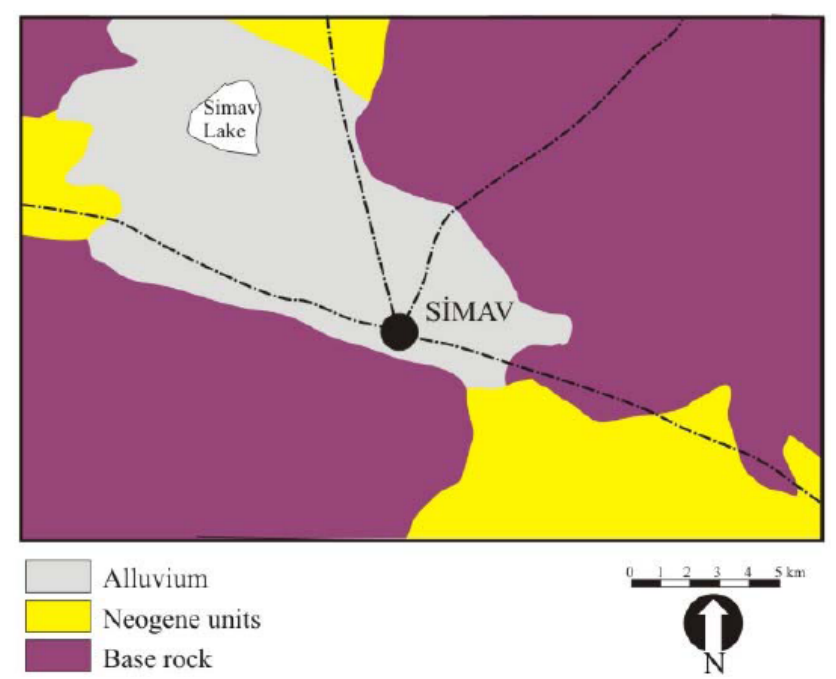

Fig. 3. Simplified geological map of Simav and its vicinity (Inel et al., 2011).

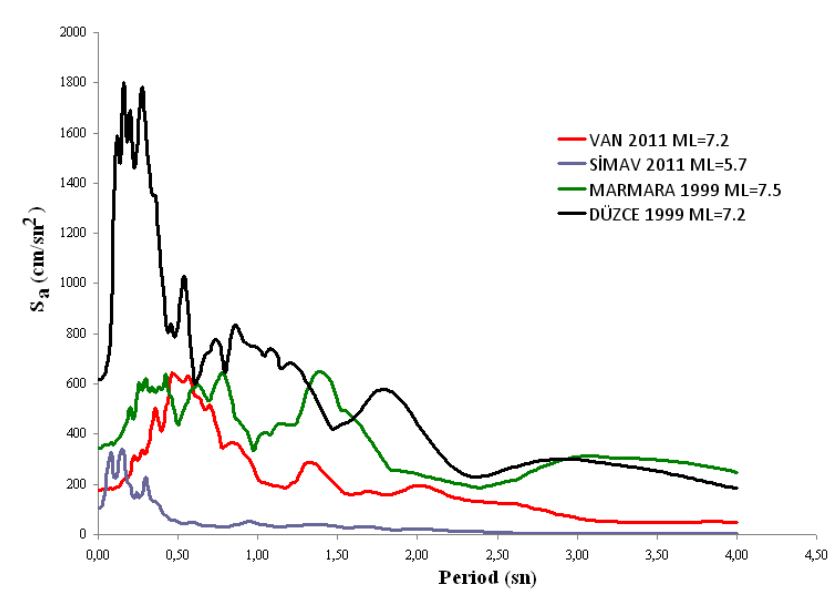

Fig. 4. Spectral acceleration values for four earthquakes in Turkey.

This clayed sediment is up to $10 \mathrm{~m}$ thick in some places, and has high plasticity and low bearing capacity.

\subsection{Characteristics of strong motion records}

The highest acceleration value of the earthquake was measured as $103.92 \mathrm{~cm} \mathrm{~s}^{-2}$ (gal) in an E-W direction in Gediz district. As a result of a study based on the $31-\mathrm{km}$ distance from the Gediz station to Simav, Inel et al. (2011) predicted the ground acceleration in an E-W direction as $247 \mathrm{~cm} \mathrm{~s}^{-2}$ at the epicenter. Spectrum values in a N-S direction are lower than those in an E-W direction. Maximum ground acceleration predicted in TEC-2007 for this region is $392.4 \mathrm{~cm} \mathrm{~s}^{-2}$. Figure 4 shows spectral acceleration with respect to the period for a damping ratio of $5 \%$. It is inferred that the earthquake impacted structures with a fundamental period of up to $0.15 \mathrm{~s}$. 


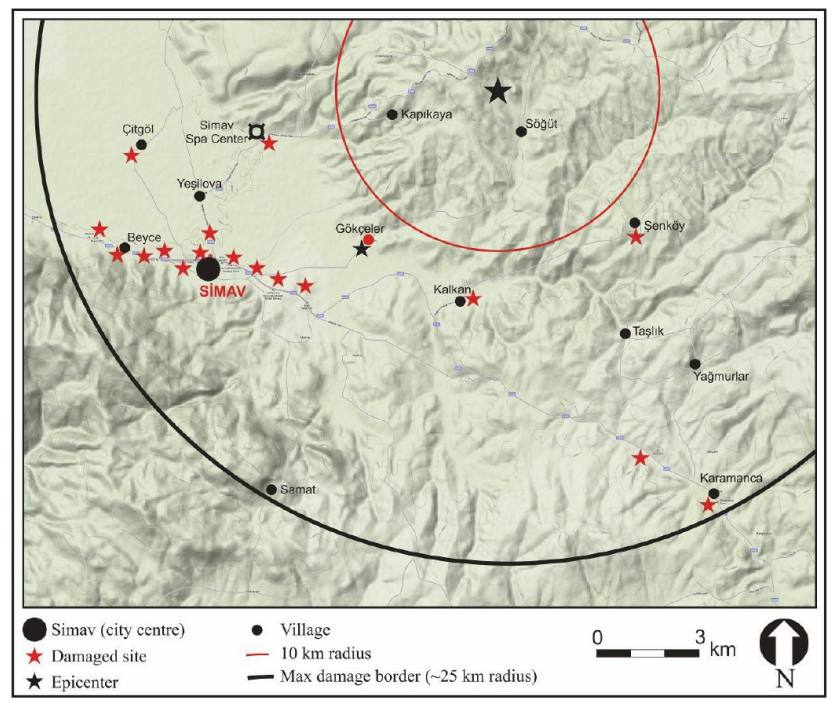

Fig. 5. Distribution of damaged areas in and around Simav (Inel et al., 2011).

\subsection{Geotechnical aspect of Simav earthquake}

Significant amounts of damage were observed in buildings located on clayed units with young lacustrine sediment, even though they were located away from the epicenter. These regions cover especially the northern part of the center of Simav. In standard penetration tests (SPT) conducted in these clay units, general average $\mathrm{N}_{30}$ values ranged between 7 and 13 (Inel et al., 2011). Considering these values, the unit can be classified as $\mathrm{C}$ or $\mathrm{D}$ soil group according to disaster regulations. Accepting that the unit thickness does not generally exceed 15 meters, territorial soil class falls within the Z2-Z3 interval. In addition, in some regions with low construction density, as the clay unit thickness exceeds $10-15 \mathrm{~m}$, the territorial soil class is Z3-Z4. Shear wave velocity $\left(\mathrm{V}_{s}\right)$ measured in this level is around $250 \mathrm{~m} \mathrm{~s}^{-1}$. Due to these features, high soil amplification values are observed in these settlement areas.

Many urban and rural settlements, especially in the center of Simav, have been settled in graben (sediment) areas. Moreover, these settlement areas are located in lacustrine alluvial soil units with high groundwater levels. This geological structure in settlement areas has become a basic control factor in terms of the effects of earthquakes on buildings. When the damage distribution in the district was examined, more damage was observed in the structures located on alluvial soil (plains) compared to those on rock fields in the south. However, the observations showed no advanced liquefaction in Simav plain in this earthquake event.

\section{Damage types in reinforced concrete structures}

The typical constructions in Turkey are RC moment-resisting frames with hollow, unreinforced clay-brick infill panels as the urban part of this area. Crack failures and collapse of infill walls, resulting in significant economic loss and human casualties, are observed on RC structures. Most of the damage to such structures occurred in locations with alluvial soil.

The clay soils in the northern part of Simav bear negative geotechnical conditions. Soil amplification is higher in these types of soil during an earthquake. In addition, soil softens under continuous loads in these types of soils and shearing resistance parameters (cohesion and angle of internal friction) decrease. When the sites of structural damage are examined, it can be seen that the effect of the earthquake extended to an area of approximately $25 \mathrm{~km}$ radius from the epicenter and there is less structural damage in the area with $10 \mathrm{~km}$ radius (red ring) (Fig. 5). One of the main reasons why significant damages were not observed in settlement areas such as Şenköy, Sögüt, and Kapıkaya even though they are close to the epicenter of the earthquake, is that structures are located on units with tighter and more rigid geotechnical features.

In Simav city center, inadequate spacing between neighboring buildings contributed to serious damage to a significant number of buildings. During the earthquake, hammering (structures contacted each other due to differences in the dynamic properties of adjacent buildings) was observed in many neighboring buildings. Similar to previous studies of earthquakes in Turkey (Adalier and Aydıngün, 2001; Sezen et al., 2003; Doğangün, 2004; Celep et al., 2011; Kaplan et al., 2004), post-earthquake observations revealed poor detailing, and a lack of appropriate reinforcement was observed in many RC framed structures in Simav. The wide shear cracks and plastic hinging at column ends indicate that poor detailing and an insufficient number of column transverse reinforcements led to catastrophic failure. In Simav a lack of stirrups at the joints was observed, making the beam-column joints vulnerable to earthquakes (Sandıkkaya et al., 2011; İnel et al., 2011; Kaplan et al., 2011). The major deficiencies of reinforcement detailing in Simav are as follows:

\section{Unsuitable transverse reinforcement (large spacing of stirrups (Fig. 6a) and lack of $\mathbf{1 3 5}$ degree hooks at the end of column ties)}

During an earthquake, some additional lateral forces are induced in a structure. These loads increases the shear forces on the structures, so, actually for columns, design of the shear reinforcement is essential. Wide spacing of lateral ties is a common shortcoming observed in Simav RC structures. During site observations after earthquakes, it is noted that the stirrup spacing was much more than the maximum value allowed by the design code TEC 2007. For most of the damaged columns, no tie spacing of less than $100 \mathrm{~mm}$ was 
observed. Often unequally spaced ties are between $150 \mathrm{~mm}$ and $300 \mathrm{~mm}$.

For TEC-2007, "hoops and crossties used in columns, beam-column joints, wall end zones and beam confinement zones of all reinforced concrete systems of high ductility level or normal ductility level in all seismic zones shall be special seismic hoops and special seismic crossties". Special seismic hoops shall always have 135 degree hooks at both ends. 90-degree hook does not provide effective anchorage since it is not embedded in the confined. Unfortunately, in Simav, 90-degree hooks have been commonly observed.

\section{Unconfined lap splices}

The strength of the lap splice is very important for the development of strength and ductility of a reinforced concrete column. According to the observation in the field, lap splices in substandard columns were typically designed as compression splices with the lap length of about 20 to 24 times bar diameter. The reason for most observed defects in damaged members is because of unconfined lap splices, inadequate anchorage lengths $(15-30 \mathrm{~cm})$, and lower longitudinal reinforcement ratios than considered in design. Also lap splices of a column longitudinal reinforcement should be made, as much as possible, within the column central zone. According to TEC 2007, lap splices in moment-frame columns were typically made immediately above the floor framing or the foundation. So, lap splices in columns were located in a plastic hinge zone which is the most critical part of RC members.

\section{Inadequate anchorage lengths}

The composite action of concrete and steel in reinforced concrete structures is provided by bond strength. The required bond strength is achieved by providing sufficient development length. In Turkish Building Code (TS-500-2000) and TEC-2007 minimum development length $l_{p}$ is given.

Lack of anchorage of beams and insufficient splice lengths is secondarily affected by low-quality levels of concrete. Damage due to poor quality of material was reported in the earthquake.

\section{Lower longitudinal reinforcement ratios than considered in design (Fig. 6a)}

The longitudinal rebar ratio $\left(\rho_{1}\right)$ ranges between $1 \%$ and $4 \%$ in TEC-2007. In TEC-2007, to increase the ductility, low steel ratio is encouraged because it is an amplification of a larger cross section. In the earthquake zone, Fig. 9a shows the columns with buckled longitudinal bars because of lower reinforcement ratio and lack of stirrups.

\section{Insufficient lateral ties at the beam-column joints}

Wide spacing of lateral ties is a common shortcoming observed by authors in Turkish RC structures. During site observations after earthquakes, it is noted that the stirrup spacing was much more than the maximum value allowed by the design code (Sandıkkaya et al., 2011; İnel, 2011; Kaplan et al., 2011), as seen in Fig. 6a. In most damaged columns, a tie spacing of less than $100 \mathrm{~mm}$ was not observed.

\section{Using plain rebar for reinforcement (low tensile quality} of steel reinforcement) (Fig. 9a)

After the earthquakes, especially widespread use of plainrebar caused bond problems coupled with insufficient splicing lengths have been observed in many RC buildings.

In addition to reinforcement detailing deficiencies, low quality concrete caused adherence problems in RC members, resulting in plastic hinging.

Taller first stories and disuse of walls for exterior cladding, in order to use the first floors as shops because of high residential densities in Simav center, caused weak and soft story problems. The building in Fig. $6 \mathrm{~b}$ collapsed as the moment frame was both flexible and weak in the first story compared with the upper stories. Deformations are concentrated in the first story of this building since the front of the building was opened on the first story. The first-story columns in this building were severely damaged and leaned onto the adjacent building. Soft story failures occur in buildings due to the sudden change of story stiffness with open fronts on the ground floor or tall ground story (excessive story height with respect to others). The most common examples are shopping malls, offices, and hotels, etc.

Because the length of the columns is less, as seen in Fig. 6c, the column becomes stiffer, more rigid in bending and receives higher shear force during an earthquake. Since the moment arm is short, the shear forces increase. The short column problem occurred due to the arrangement of infill walls due to window openings in the base floor. In TEC2007, where shear force short columns cannot be avoided, very stringent requirements for transverse reinforcement of short columns are put forward, which are taken into account for the design of transverse reinforcement of columns. Figure $6 \mathrm{c}$ is a good example of this kind of short column damage from Simav Earthquake.

\section{A short description of surveyed RC buildings in the region}

More than thirty government buildings were surveyed in Kütahya city center and its districts by authors. Survey teams have conducted necessary measurements and took adequate concrete samples and carried out destructive as well as nondestructive tests to obtain member sizes, member detailing 


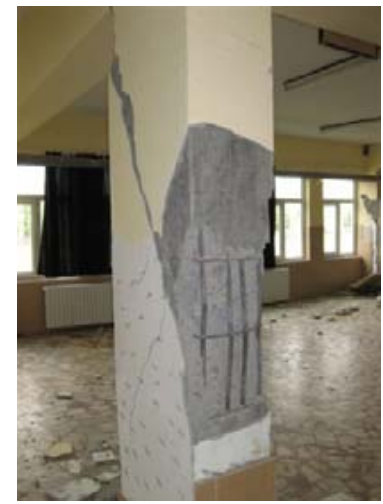

a- Lack of stirrups at the joints

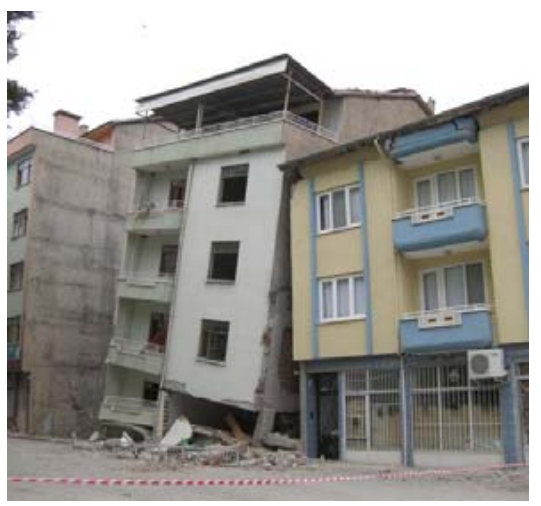

b- Failure on first floor due to soft story

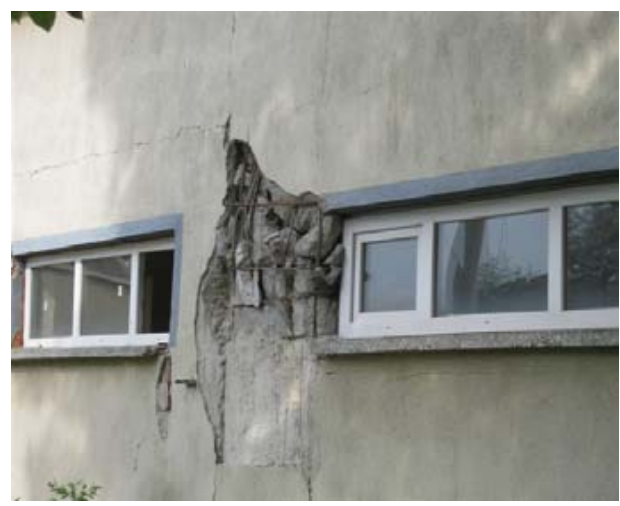

c- Short column failure

Fig. 6. Three damage types from epicenter region.

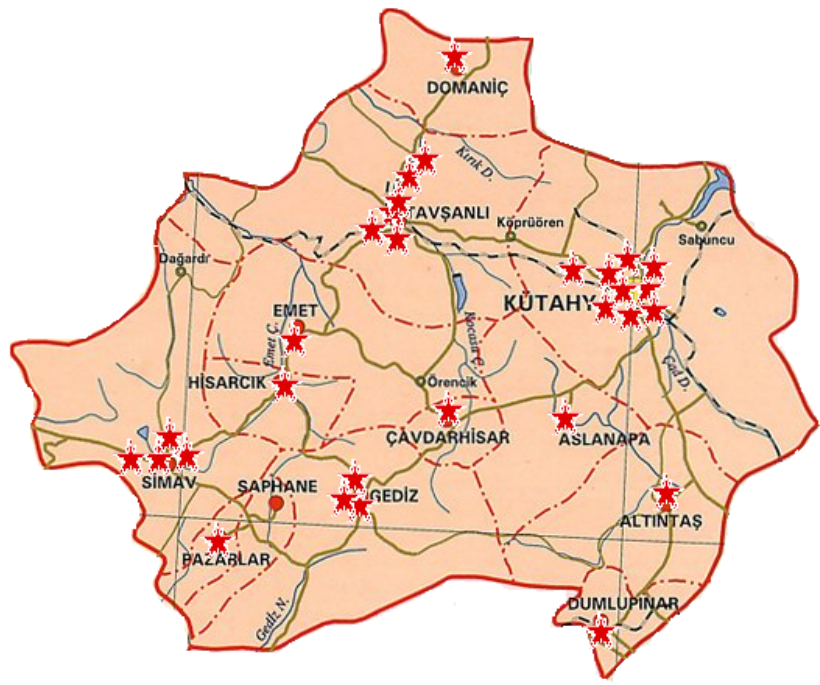

Fig. 7. Geographical distributions of the buildings studied.

and the mechanical properties of the materials. As indicated later, at least three core samples per story were taken to determine the building-specific concrete compressive strength to be used in the performance analysis.

All buildings had different construction dates, numbers of stories, and flat areas given in Table 2. The damages in the buildings were classified into four ranks during the investigation given in Table 2: (1) light and no damage; (2) minor damage; (3) medium damage; (4) major damage. Geographical distributions of the buildings studied are shown and marked in Fig. 7. It is clearly seen that all buildings are located in the earthquake region.

Distribution of concrete compressive strength shown in Table 2 reveals that the concrete compressive strength was generally between 4.9-18.2 MPa with an average value of ap-

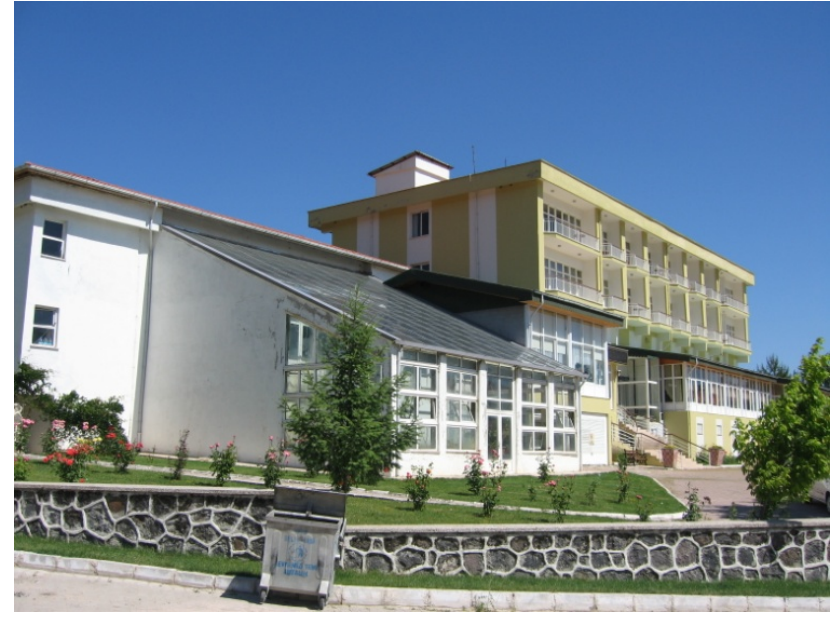

Fig. 8. Building facade and lateral facade (case study 1).

proximately $6.76 \mathrm{MPa}$. It is worth noting that the current code TEC-2007 requires a minimum of $20 \mathrm{MPa}$ for the design of buildings. From visual inspection, it has been observed that generally plain bars with a characteristic yield strength of nearly $220 \mathrm{MPa}$ were used.

The majority of the surveyed buildings' structural systems were made of RC with varying percentages in the column and shear wall area. Since the density of shear walls in a given principal direction is believed to have a prominent role in the seismic performance of the buildings (Arslan and Korkmaz, 2007; Çağatay, 2005; Inel et al., 2008; Tan et al., 2008; Adalier and Aydıngün, 2001; Sezen et al., 2003; Doğangün, 2004; Celep et al., 2011; Kaplan et al., 2004), it is not surprising to observe that most of the buildings have no shear walls. 
Table 2. Description of government buildings surveyed by the team.

\begin{tabular}{|c|c|c|c|c|c|c|c|c|c|}
\hline Location & $\begin{array}{l}\text { Construction } \\
\text { type }\end{array}$ & $\begin{array}{l}\text { Construction } \\
\text { date }\end{array}$ & $\begin{array}{l}\text { Number of } \\
\text { story }\end{array}$ & $\begin{array}{l}\text { Stories } \\
\text { area }\end{array}$ & $\begin{array}{l}\text { Total area } \\
\text { core samples }\end{array}$ & $\begin{array}{l}\text { Number of } \\
\text { resistance of } \\
\text { core samples }(\mathrm{MPa})\end{array}$ & $\begin{array}{l}\text { Average compression } \\
\text { rebar type }\end{array}$ & Steel & $\begin{array}{l}\text { Damage } \\
\text { type }\end{array}$ \\
\hline $\mathrm{KCC}$ & $\mathrm{RC}$ & 1994 & 5 & 1097 & 5485 & 15 & 6.3 & S220 & 1 \\
\hline $\mathrm{KCC}$ & $\mathrm{RC}$ & 1988 & 3 & 188 & 564 & 9 & 11.7 & S220 & 1 \\
\hline $\mathrm{KCC}$ & $\mathrm{RC}$ & 1987 & 5 & 160 & 800 & 15 & 4.85 & $\mathrm{~S} 220$ & 1 \\
\hline $\mathrm{KCC}$ & $\mathrm{M}$ & 1968 & 3 & 145 & 435 & - & - & - & 1 \\
\hline $\mathrm{KCC}$ & $\mathrm{RC}$ & 1991 & 1 & 263 & 263 & 4 & 9.9 & S220 & 1 \\
\hline $\mathrm{KCC}$ & $\mathrm{M}$ & 1957 & 2 & 329 & 658 & - & - & - & 1 \\
\hline $\mathrm{KCC}$ & $\mathrm{RC}$ & 1975 & 1 & 525 & 525 & 3 & 4.8 & S220 & 1 \\
\hline $\mathrm{KCC}$ & $\mathrm{RC}$ & 2003 & 1 & 616 & 616 & 3 & 18.2 & S420 & 1 \\
\hline Gediz & $\mathrm{RC}$ & 2003 & 3 & 300 & 900 & 9 & 12.5 & S420 & 1 \\
\hline Gediz & $\mathrm{RC}$ & 1977 & 4 & 120 & 480 & 12 & 5.1 & $\mathrm{~S} 220$ & 1 \\
\hline Gediz & $\mathrm{RC}$ & 1992 & 2 & 300 & 600 & 6 & 4.9 & S220 & 2 \\
\hline Tavşanlı & $\mathrm{RC}$ & 1994 & 5 & 550 & 2750 & 15 & 8.5 & S220 & 2 \\
\hline Tavşanlı & $\mathrm{RC}$ & 1988 & 5 & 320 & 1600 & 15 & 7.2 & S220 & 1 \\
\hline Tavşanlı & $\mathrm{RC}$ & 1978 & 3 & 150 & 450 & 9 & 5.6 & $\mathrm{~S} 220$ & 1 \\
\hline Tavşanlı & $\mathrm{RC}$ & 2000 & 1 & 360 & 360 & 3 & 6.4 & S220 & 1 \\
\hline Tavşanlı & $\mathrm{RC}$ & 1997 & 1 & 174 & 174 & 3 & 8.2 & S220 & 1 \\
\hline Tavşanlı & $\mathrm{RC}$ & 1997 & 2 & 177 & 354 & 3 & 7.1 & $\mathrm{~S} 220$ & 1 \\
\hline Emet & $\mathrm{RC}$ & 1986 & 5 & 340 & 1700 & 18 & 5.4 & S220 & 1 \\
\hline Simav & $\mathrm{RC}$ & 2008 & 4 & 342 & 1368 & 12 & 18.2 & S420 & 1 \\
\hline Simav & M & 1951 & 2 & 216 & 432 & - & - & - & 1 \\
\hline Altıntaş & $\mathrm{RC}$ & 1994 & 2 & 340 & 680 & 6 & 6.8 & S220 & 2 \\
\hline Domaniç & $\mathrm{RC}$ & 1997 & 2 & 280 & 560 & 6 & 6.2 & $\mathrm{~S} 220$ & 1 \\
\hline Hisarcık & $\mathrm{RC}$ & 1999 & 2 & 280 & 560 & 6 & 6.4 & S220 & 2 \\
\hline Pazarlar & $\mathrm{M}$ & 1962 & 1 & 216 & 216 & - & - & - & 1 \\
\hline Aslanapa & $\mathrm{RC}$ & 2009 & 2 & 228 & 456 & 6 & 15.1 & S420 & 1 \\
\hline Dumlupınar & M & 1987 & 2 & 149 & 298 & - & - & - & 1 \\
\hline Çavdarhisar & $\mathrm{RC}$ & 1996 & 3 & 262 & 540 & 15 & 7.9 & S220 & 1 \\
\hline Dumlupinar & M & 1970 & 2 & 160 & 320 & - & - & - & 3 \\
\hline Simav-Case 1 & $\mathrm{RC}$ & 1990 & 5 & 515 & 2574 & 15 & 8.1 & S220 & $3-4$ \\
\hline Simav-Case 2 & $\mathrm{RC}$ & 1997 & 6 & 282 & 1696 & 18 & 6.7 & S220 & $3-4$ \\
\hline Yoncalı & $\mathrm{M}$ & 1993 & 1 & 800 & 800 & - & - & - & 2 \\
\hline
\end{tabular}

KCC: Kutahya City Center, RC: Reinforced Concrete, M: Masonry

\section{Seismic performance assessment of RC buildings according to TEC-2007}

Within seismic codes, the earthquake safety of existing $\mathrm{RC}$ buildings is determined based on the concept of performance-based design. Generally this takes the form of the desired performance outcomes, such as withstanding minor earthquakes undamaged, withstanding medium-scale earthquakes with limited damage, and withstanding largescale earthquakes without total collapse. The critical outcome is prevention of total structural collapse. This means that the upper level withstands total collapse (CP); the sub level, for the crucial structures, may be slightly damaged but remains fit for immediate occupancy (IO). Between the sub and upper levels there is a life safety (LS) level situation. Multiple performance objectives for these levels, including the seismic transformation periods, have been specified in Table 3.

In Turkey two main codes influence the design and construction of RC buildings: TEC-2007 and TBC-500-2000. TEC includes procedures for calculating earthquake loads on buildings and determining earthquake performance of existing structures. This code includes specifications for ductile

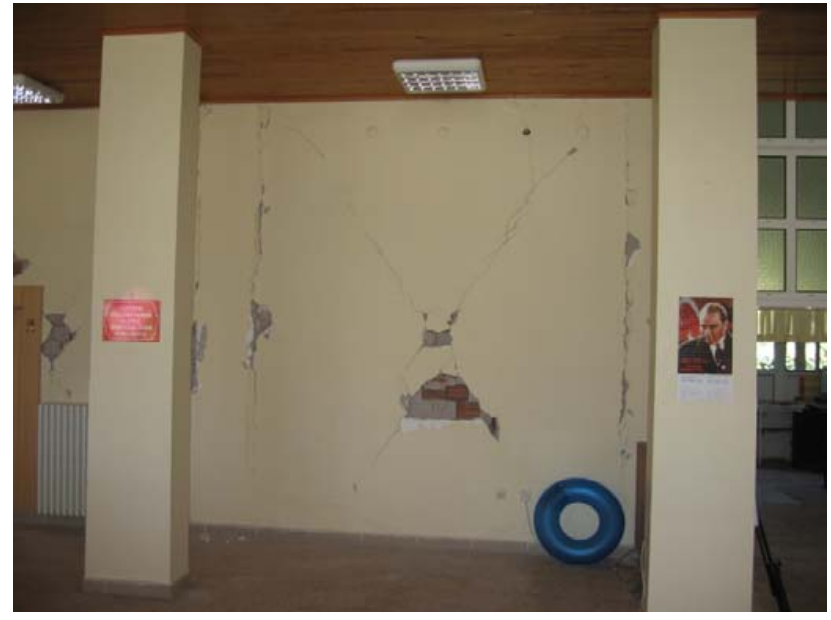

Fig. 9. Filled wall damage.

design of column, beam, and shear wall elements. The TBC includes requirements for the design and detailing of $\mathrm{RC}$ components but does not include ductile detailing requirements for use in seismic design. 
Table 3. Structure performance based on damage in Turkish Earthquake Code (TEC-2007).

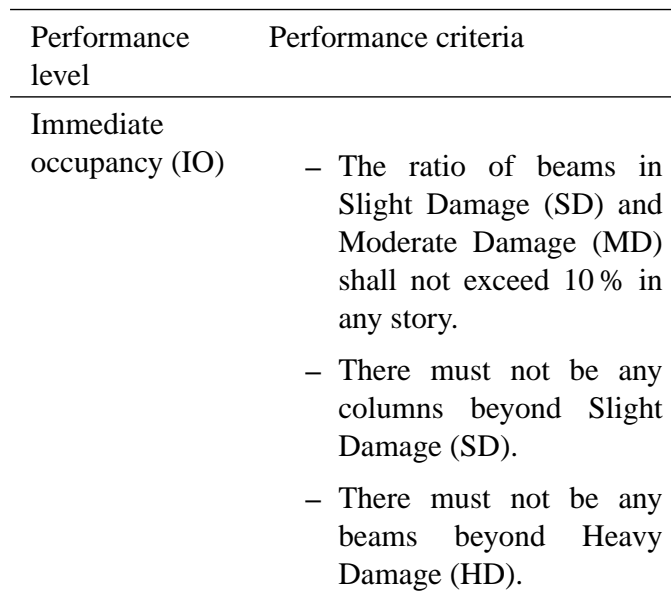

Life Safety

(LS) - The ratio of beams in Moderate Damage (MD) and Heavy Damage (HD) shall not exceed $30 \%$ in any story.

- In any story, the shear force carried by columns in Heavy Damage (HD) shall not exceed $20 \%$ of story shear.

\section{Collapse}

Prevention (CP)

- The ratio of beams in Heavy Damage (HD) must not exceed $20 \%$ in any story.

- In any story, the shear force carried by column that passed Slight Damage (SD) must not exceed $30 \%$ of story shear force.

Collapse

(C) - If the failure can not be prevented, it is under failure condition.

When a short history of earthquake codes is considered, the earthquakes in Turkey and the code revisions occur at similar times. The recently published version of the TEC2007 includes seismic performance evaluation and seismic retrofitting sections that are parallel to those in FEMA-356 and FEMA-440. Like FEMA-356, TEC-2007 states that the seismic performance of buildings can be determined using linear or non-linear analysis; the design engineer is free to utilize either linear or non-linear analysis approaches. Short procedure seismic performance assessment of an RC building in TEC-2007 is given below:

1. Collecting data from existing $\mathrm{RC}$ building (structural layout, plan and vertical dimensions, number of stories and architectural features such as soft and weak stories and overhangs, short column formations etc., obtained concrete average compressive strength, steel yield strength, steel type, stirrups spacing in the confinement regions, identification of soil type).

2. 3-D modeling by using obtained data from the existing $\mathrm{RC}$ building.

3. Performance analysis according to the selected methods (Linear or non-linear) in the code.

4. Judging the performance of existing RC buildings.

\subsection{Non-linear seismic performance assessment in TEC-2007}

The purpose of the non-linear analysis methods is to determine the structural performance of existing $\mathrm{RC}$ buildings under seismic loading. In TEC-2007, the earthquake safety of existing RC buildings is determined based on a performancebased design. The non-linear evaluation method considers the elasto-plastic behavior of the structural system and the main application procedure is incremental equivalent seismic analysis according to the single mode.

The objective is to carry out the non-linear static analysis under incrementally increasing seismic forces, distributed in accordance with the dominant mode shape in the earthquake displacement, until demand is reached. Internal member forces and plastic deformations are calculated at the demand level. After the plastic rotation demands of ductile members are calculated, these values are compared and defined in Table 4.

The seismic performance of the load-bearing system is defined as the sum of seismic damage levels of the structural elements (e.g., beams and columns) that form the load-bearing system. As part of the static pushover analysis, it is necessary to define the cross-sectional damage level according to the deformation of each of the structural elements in order to determine the global performance of the load-bearing system. Table 4 shows cross-sectional damage types according to TEC-2007.

TEC 2007 defines the performance limits of deformations of RC elements as maximum unit deformations, calculated in concrete and rebar in the section. Limit values given in unit 
Table 4. Cross-sectional damage levels.

\begin{tabular}{lll}
\hline Cross-sectional damage level & Maximum strain for concrete $\left(\varepsilon_{\mathrm{c}}\right)$ & Maximum strain for steel $\left(\varepsilon_{s}\right)$ \\
\hline Slight Damage (SD) & 0.0035 & 0.010 \\
Moderate Damage (MD)* & $0.0035+0.01\left(\frac{\rho_{s}}{\rho_{s m}}\right) \leq 0.0135$ & 0.040 \\
Heavy Damage (HD)** & $0.004+0.014\left(\frac{\rho_{s}}{\rho_{s m}}\right) \leq 0.018$ & 0.060 \\
\hline
\end{tabular}

${ }^{*}$ and ${ }^{* *}$ : Deformation values in the outer fiber of the stirrup.

deformation terms were defined in terms of plastic bending by using moment-bending relationships calculated primarily for the section. The plastic bend value is determined according to whether concrete or steel fiber reaches the abovementioned limit values first. The plastic bend value is then multiplied by the plastic hinge length $\left(L_{\mathrm{p}}=0.5 h\right)$ given in TEC-2007 in order to obtain plastic bending. In the equation given in Table $4, \rho_{\mathrm{sm}}$ is the volume ratio of minimum transverse reinforcement in the confinement zone, calculated according to TEC-2007 [13]; $\rho_{\mathrm{s}}$ is the volume ratio of transverse reinforcement in the existing section.

Pre-yield linear behavior of reinforced concrete section is represented by cracked sections, which is $0.4 \mathrm{EI}_{o}$ for flexural members (such as beams), and varies between $0.40-0.80 \mathrm{EI}_{o}$ for axial loaded columns. In the analyses, strain hardening in the plastic hinge range can be ignored.

\section{Case studies}

The sample buildings have been selected from the surveyed buildings in the region. The sample buildings that have been explained in detail were the best examples of their structural type among the more than thirty buildings. The buildings designed and constructed before the TEC-1998 seismic code have similar structural deficiencies observed after the earthquake in Turkey. The structural system and the geometry of these buildings are thought to represent the current RC structural stock of Turkey. The sample buildings have been marked in bold in Table 2 .

\subsection{Case study 1}

\subsubsection{Brief description of the selected existing RC buildings}

The building used as case study 1 is located in the Simav district of Kütahya Province. It comprises 5 stories: 1 basement, 1 ground story, 1 installation story, and 2 typical stories. The building was constructed in 1990. The facade of the building is shown in Fig. 8. The load-bearing system of the building was planned as a reinforced concrete frame. The floor system of the building was beam slab with slab thickness of $12 \mathrm{~cm}$. In situ measurements of columns, which are the vertical bearing elements, determined that the columns

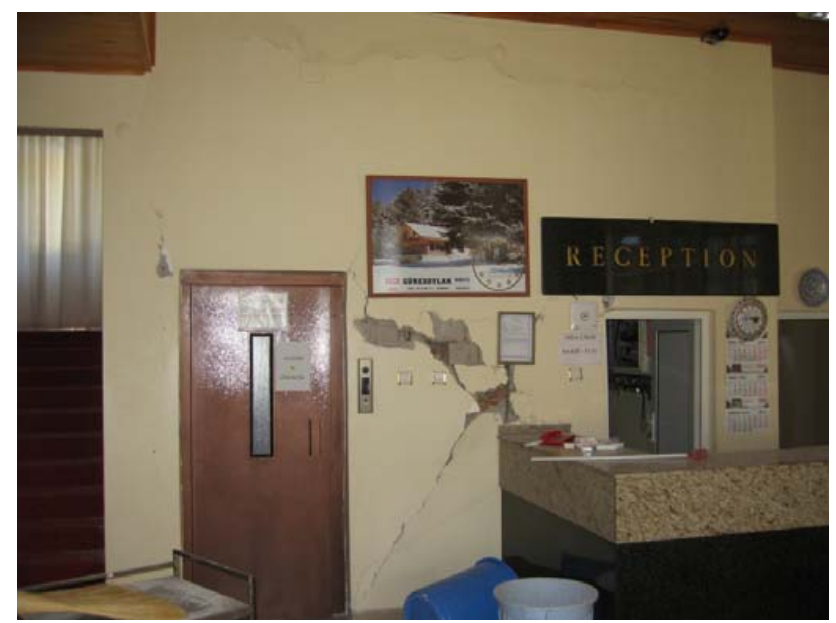

Fig. 10. Filled wall damage.

were $30 \mathrm{~cm} \times 50 \mathrm{~cm}, \quad 50 \mathrm{~cm} \times 60 \mathrm{~cm}, \quad 30 \mathrm{~cm} \times 55 \mathrm{~cm}$, and $25 \mathrm{~cm} \times 50 \mathrm{~cm}$ rectangular sections. RC shear wall existed only in the elevator shaft in lead system. Beams were 20 $\mathrm{cm} \times 60 \mathrm{~cm}$ and $25 \mathrm{~cm} \times 60 \mathrm{~cm}$. Story heights were $3.00 \mathrm{~m}$ in the basement, $4.00 \mathrm{~m}$ in the ground story, $2.25 \mathrm{~m}$ in the installation story and $3.20 \mathrm{~m}$ in each typical story.

Non-load partition walls were particularly badly damaged in the earthquake. Partition walls were separated from the frame due to both in-plane and out-of-plane movements. Damage was especially severe around the walls of subfloors (Figs. 9 and 10). The architect of the project removed significant parts of the ground story walls due to the projected usage of the building even though the project originally included them.

Diagonal fractures occurred in significant parts of the infilled walls through the dissipation of energy. Therefore, no significant damage was observed in load-bearing elements (column, beam, etc.). In addition, the ribbon windows of the basement story in the rear facade of the building caused shear cracks in upper bearings of columns (short column mechanism). Figure 11 shows the appearance of short column forming.

Unsupervised construction and even design factors are important causes of damage in the relevant building (and other government buildings in Simav district) sustained during the earthquake. The examinations indicated frequent mistakes 


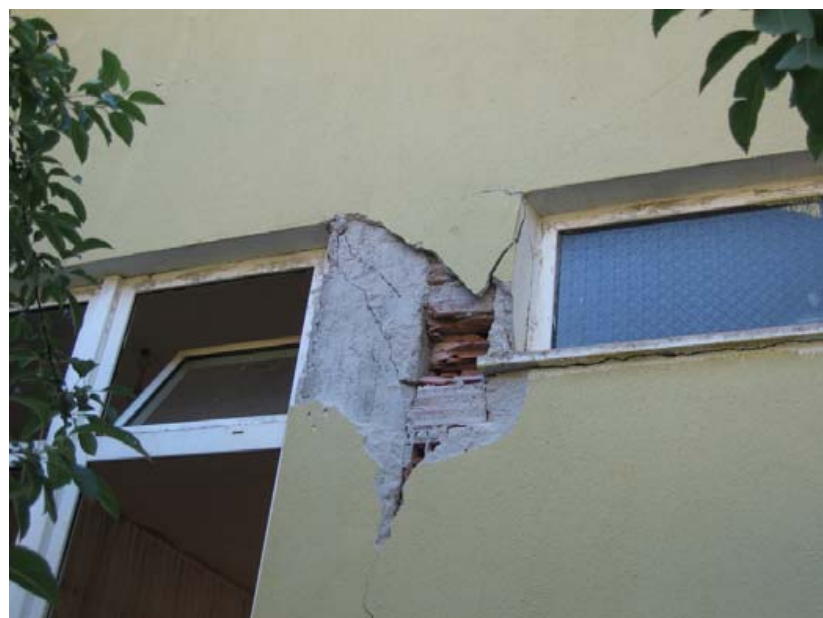

Fig. 11. Shear-column damage.

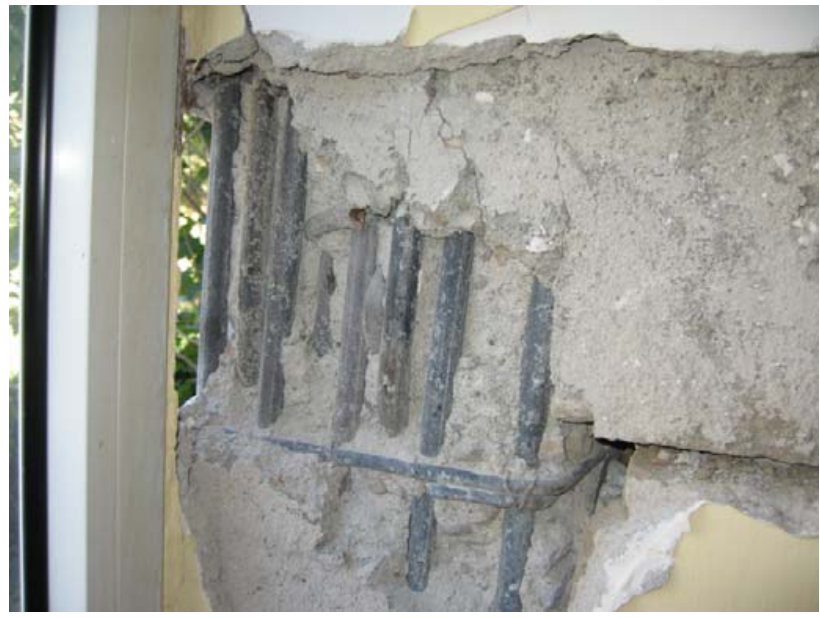

Fig. 12. Utilized rebar (beam-column node of ground story).

that cannot be explained with principles of RC construction. The basic causes of damage are defects in the placement and the mechanical characteristics of transverse and longitudinal rebar, low concrete quality, inappropriate wall construction, and the increased height and low rigidity of the ground story compared to other floors. The beam-column connection region shown in Fig. 12 demonstrates that the building is far from complying with the provisions of TEC-2007. There is no stirrup in the column and beam connection region, stirrups hooks have 90 degree angles, there is hooking in the compression rebar, and the distance between rebars is noncompliant.

\subsubsection{Seismic performance assessment according to TEC-2007}

The evaluations according to the TEC-2007 norms primarily determined on-site values of the load-bearing system of the

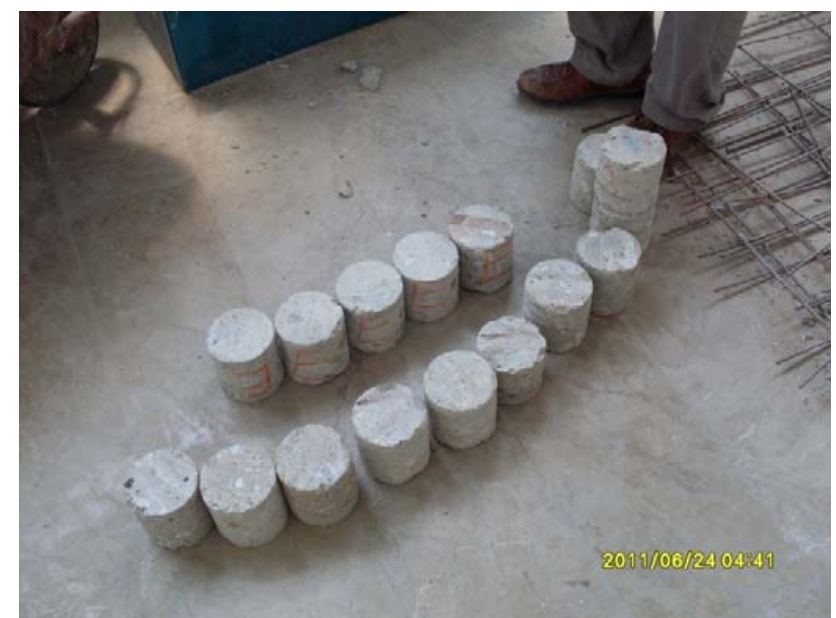

Fig. 13. Obtained core samples.

building. After completing the general geometrical survey to determine the characteristics of the as-built project, a detailed experimental program was planned. This program includes on-site destructive testing and laboratory tests on the specimens (core members) obtained from the structural elements, in order to evaluate the mechanical properties of concrete materials (Fig. 13). The experiments were conducted in the Earthquake and Construction Laboratory of Selcuk University. Average concrete compression resistance of the building was found to be $8.1 \mathrm{MPa}\left(f_{\mathrm{c}}=81 \mathrm{~kg} \mathrm{~cm}^{-2}\right)$. The compressive strengths of the core members are given in Table 5. Observations made during the search-and-rescue phase and core-removal works at the site suggested that the quality of the concrete used was extremely insufficient. Examination of the concrete core samples obtained from the building found that the concrete aggregates had been used in their natural states without being washed and sieved, and the grain size distribution was not suitable for a high quality concrete.

The class of steel rebar used in the building was S220 $\left(f_{y}=220 \mathrm{MPa}\right)$. The rebars in the load system elements were located using a rebar detection device; the number and diameters of rebars were determined, and accurate rebar distribution was recorded in the model. It was found that confinement intervals in columns and beams were about $17-25 \mathrm{~cm}$. The examinations determined that the vertical (longitudinal) rebar ratio in columns was approximately $0.8 \%-1.0 \%$.

Soil core samples showed that the territorial soil class is Z3, which is similar to class C soil in FEMA-356. TEC-2007 specifies spectrum characteristic periods as $0.15 \mathrm{~s}$ and $0.60 \mathrm{~s}$ in this type of soil. The building is located on Quaternary old alluvial, which is classified as clayey sand (SC; USCS classification system). SPT number $\mathrm{N}_{30}$ in the soil generally ranges between 7 and 30. In a field where the depth of the groundwater level is between 4.5 and $7.0 \mathrm{~m}$, topographic inclination is about $0-5 \%$. According to TEC-2007, in a field where soil class is $\mathrm{C}$ and territorial soil class is Z3, groundwater level is 
Table 5. Compressive test results of the concrete specimens - case study 1 .

\begin{tabular}{lllllll}
\hline Specimen No. & $\mathrm{r} / \mathrm{h}$ & $\lambda=\mathrm{h} / \mathrm{r}$ & $\mathrm{P}(\mathrm{kN})$ & $\begin{array}{l}\mathrm{f}_{\lambda, d} \\
\mathrm{P} / \mathrm{A}(\mathrm{MPa})\end{array}$ & $\begin{array}{l}\mathrm{f}_{\varphi 15 / 30} \\
(\mathrm{MPa})\end{array}$ & $\begin{array}{l}\mathrm{f}_{15 \times 15 \times 15} \\
(\mathrm{MPa})\end{array}$ \\
\hline $\mathrm{N}_{1}$ & $93 / 93$ & 1.00 & 67 & 9.86 & 8.38 & 9.86 \\
$\mathrm{~N}_{2}$ & $93 / 93$ & 1.00 & 124 & 18.26 & 15.52 & 18.26 \\
$\mathrm{~N}_{3}$ & $93 / 93$ & 1.00 & 44 & 6.48 & 5.51 & 6.48 \\
$\mathrm{~N}_{4}$ & $93 / 93$ & 1.00 & 97 & 14.29 & 12.14 & 14.29 \\
$\mathrm{~N}_{5}$ & $93 / 93$ & 1.00 & 67 & 9.87 & 8.39 & 9.87 \\
$\mathrm{~N}_{6}$ & $93 / 93$ & 1.00 & 84 & 12.27 & 10.43 & 12.27 \\
$\mathrm{~N}_{7}$ & $93 / 93$ & 1.00 & 75 & 11.05 & 9.39 & 11.05 \\
$\mathrm{~N}_{8}$ & $93 / 93$ & 1.00 & 71 & 10.46 & 8.89 & 10.46 \\
$\mathrm{~N}_{9}$ & $93 / 93$ & 1.00 & 82 & 12.07 & 10.26 & 12.07 \\
$\mathrm{~N}_{10}$ & $93 / 93$ & 1.00 & 69 & 10.16 & 8.64 & 10.16 \\
$\mathrm{~N}_{11}$ & $93 / 93$ & 1.00 & 73 & 10.75 & 9.14 & 10.75 \\
$\mathrm{~N}_{12}$ & $93 / 93$ & 1.00 & 92 & 13.55 & 11.52 & 13.55 \\
$\mathrm{~N}_{13}$ & $93 / 93$ & 1.00 & 75 & 11.04 & 9.38 & 11.04 \\
$\mathrm{~N}_{14}$ & $93 / 93$ & 1.00 & 81 & 11.93 & 10.14 & 11.93 \\
$\mathrm{~N}_{15}$ & $93 / 93$ & 1.00 & 69 & 10.16 & 8.64 & 10.16 \\
\hline
\end{tabular}

$$
f_{\mathrm{cm}}=\frac{\sum f_{\mathrm{c}}}{m}=11.48 \mathrm{MPa}, \quad \sigma_{\mathrm{c}}=\left[\frac{\sum_{1}^{m}\left(f_{\mathrm{cm}}-f_{\mathrm{c}}\right)^{2}}{m}\right]^{1 / 2}=3.38 \mathrm{MPa}, \quad f_{\mathrm{c}}=f_{\mathrm{cm}}-\sigma_{\mathrm{c}}=8.10 \mathrm{MPa}
$$

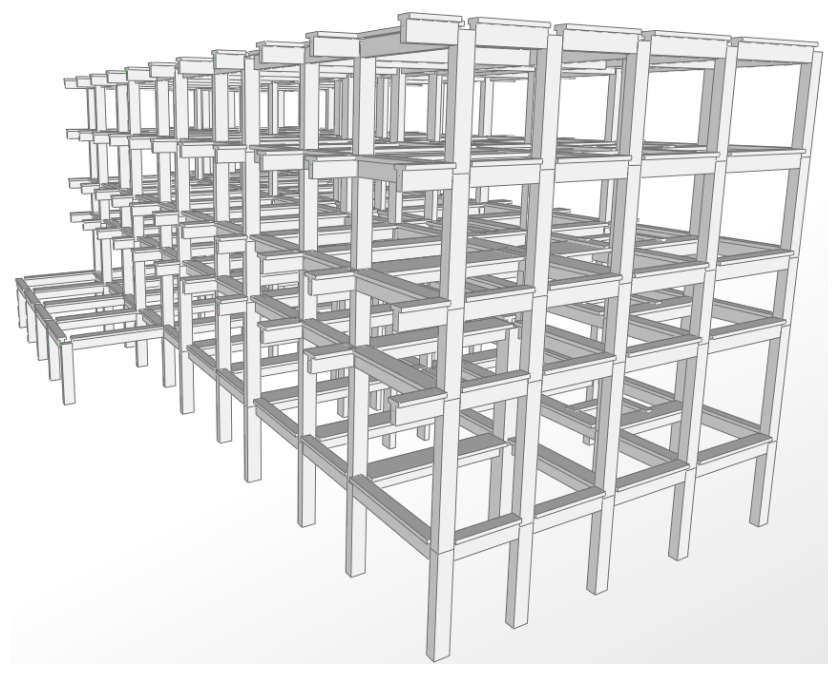

Fig. 14. Case study 1 (3-D structural model).

close to the surface and no liquefaction is observed, which depends on the existence of significant amounts of clay and aggregates in the soil.

Structural analysis was conducted to determine soil, material and dimension information. For the performance analysis, SAP2000 was used. The 3-D image from the program is presented in Fig. 14.

The static pushover analysis method was selected to obtain the lateral load-lateral top displacement curve of a sample

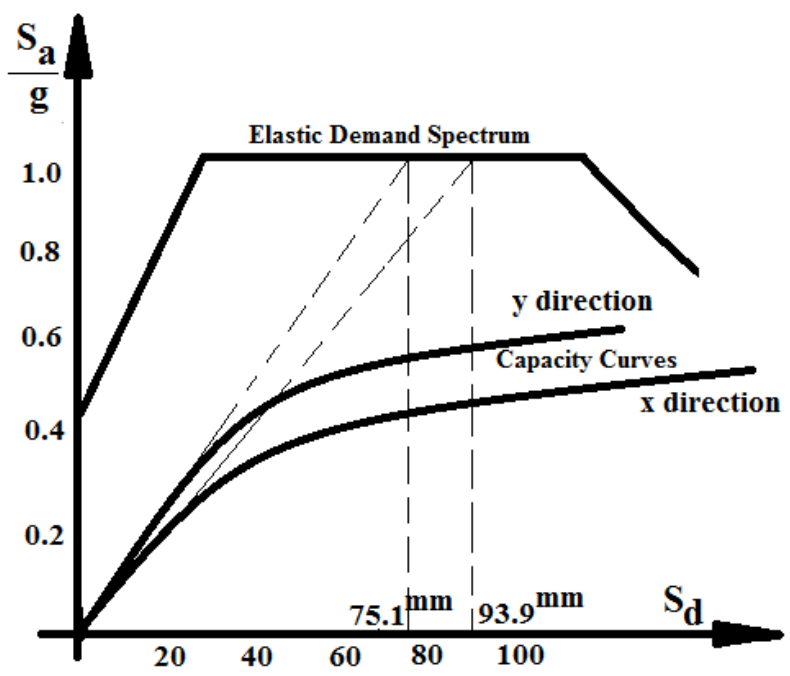

Fig. 15. Capacity curves at $\mathrm{x}$ and $\mathrm{y}$ directions for case study 1 .

building. This method is implemented by incrementing the equivalent seismic load proportional to the multiplication of the first (domain) vibration mode shape amplitudes and story masses in the considered earthquake direction.

In order to obtain lateral load-lateral top displacement curve of the sample buildings, 3-D (three-dimensional) models have been created in SAP2000. Beam and column element are modeled as non-linear frame elements with lumped 


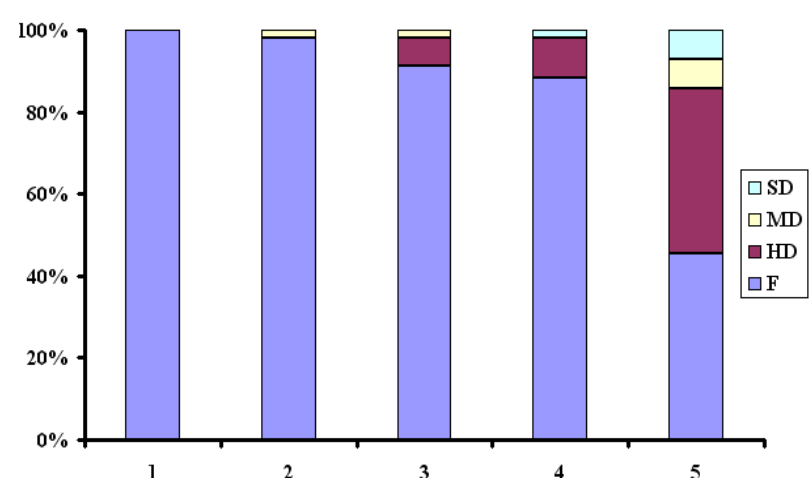

Fig. 16. Column cross-sectional damage.

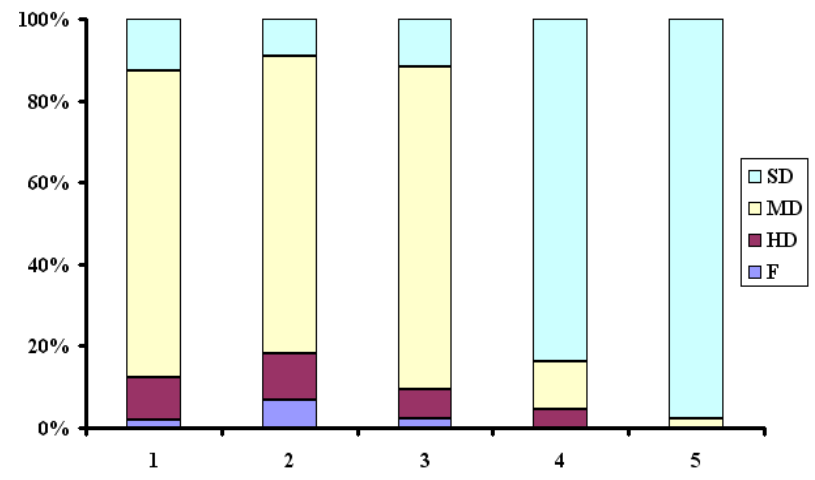

Fig. 17. Beam cross-sectional damage.

plasticity by defining plastic hinges at both ends of the beams and columns. To define plastic hinge properties, momentcurvature analyses are carried out taking into account section properties and axial load level for every column and beam. Instead of default values for hinge properties in SAP2000, the moment-curvature relations are obtained by using an Excel macro. The input required for the above-mentioned programs is moment rotation instead of moment curvature; therefore, transformation is needed. In this step, a suitable plastic hinge length $\ell_{\mathrm{p}}$ is assumed as half of the section depth. This relation is also used in TEC-2007 and FEMA-356. In the analysis P- $\Delta$ effects were taken into account. Additional accidental eccentricities have not been applied, building importance factors have been ignored, and infinitely rigid end zones were defined at the beam/column connections in the analyses as recommended by TEC2007.

After modeling, the performance of the building was determined according to TEC-2007 norms. Base shear capacityroof displacement curve for non-linear procedures have been converted to the spectral displacement-spectral acceleration curve. Using the results obtained from analysis, the performance level of the building is determined by using strain values given in TEC-2007. In the other words, earthquake

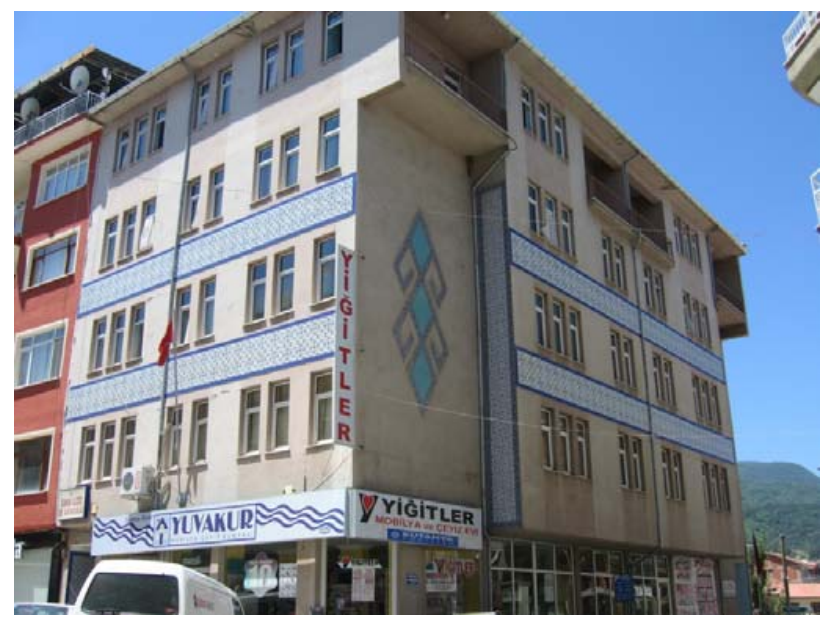

Fig. 18. Lateral facade of the building.

performance level of buildings has been determined after determining the cross-sectional (member) damage states.

The reference design spectrum in TEC-2007 has $10 \%$ probability of exceeding in $50 \mathrm{yr}$, corresponding to a $475-\mathrm{yr}$ return period.

Figure 15 shows load-displacement (capacity) curves for both directions, where the elastic spectrum curve is the level of design earthquake for 1st degree earthquake zone determined in TEC-2007. In addition, Figs. 16 and 17 show the damage criteria of columns and beams comprising the load system, shown according to floors and proportionally, respectively. According to the analysis results, $100 \%$ of the columns are in the significant damage region in the first story. Using this method, the global performance level of the building was determined to be total collapse (CP) according to TEC-2007.

\subsection{Case study 2}

\subsubsection{Brief description of the selected existing sample RC buildings}

The building used as case study 2 is located in the Simav district of Kütahya Province. It comprises 6 stories: a basement, ground story, and 4 typical floors. The building was constructed in 1997. The facade of the building is shown in Fig. 18. The load-bearing system of the building was planned as a concrete framework. The floor system of the building was beam slab, with slab thickness of $12 \mathrm{~cm}$. Floor heights were $3.00 \mathrm{~m}$ in the basement, $3.50 \mathrm{~m}$ in the ground story, and $3.00 \mathrm{~m}$ in typical floors. In situ measurements of columns, as load-bearing elements, showed that they are $25 \mathrm{~cm} \times 70 \mathrm{~cm}, \quad 30 \mathrm{~cm} \times 70 \mathrm{~cm}, 30 \mathrm{~cm} \times 80 \mathrm{~cm}$, $30 \mathrm{~cm} \times 180 \mathrm{~cm}, \quad 30 \mathrm{~cm} \times 150 \mathrm{~cm}, \quad 30 \mathrm{~cm} \times 200 \mathrm{~cm}$, and $20 \mathrm{~cm} \times 200 \mathrm{~cm}$ rectangular sections. The elevator shaft in the load system was planned as a shear wall. The beams were $20 \mathrm{~cm} \times 60 \mathrm{~cm}$ and $30 \mathrm{~cm} \times 60 \mathrm{~cm}$. 
After the earthquake, damage was observed to be especially severe in non-load partition walls. Partition walls were separated from the framework system as a result of in-plane and out-of-plane movements. Figure 19 shows some samples of such damage. Damage was more severe in lower floors. In addition to filled walls, cross-sectional cracks were observed in shear columns $(\sim 30 \mathrm{~cm} \times 180 \mathrm{~cm}-30 \mathrm{~cm} \times 200 \mathrm{~cm}$ size $)$ in the ground story. These elements, which serve for the safety of the building, had slight-medium damage and prevented total collapse of the building.

\subsubsection{Seismic performance assessment according to TEC-2007}

The process steps defined for case 1 were repeated for this second building, and necessary information about materials, section, and ground conditions was obtained. The average concrete compression resistance of the building was found to be $6.7 \mathrm{MPa}\left(f_{\mathrm{c}}=67 \mathrm{~kg} \mathrm{~cm}^{-2}\right)$. The compressive strengths of the core members are given in Table 6 . The core samples had been taken from non-damaged column and shear wall members.

The remarkable finding for this building was the failure of aggregate granulometry. The yield strength of the steel used in the building was $220 \mathrm{MPa}$ and the rebar was smooth. Densification in columns and beams was not observed in this building. The territorial soil class is $\mathrm{Z} 3$, which is similar to class $\mathrm{C}$ soil in FEMA-356, and allowable bearing capacity is $0.10 \mathrm{MPa}\left(1 \mathrm{~kg} \mathrm{~cm}^{-2}\right)$. The building is located on Quaternary old alluvial soil, which can be classified as clayey sand (SC) according to the USCS classification system. SPT number $\mathrm{N}_{30}$ generally ranged between 10 and 20 , and the depth of the groundwater level was $10 \mathrm{~m}$ below the surface. Terzaghi and Peck (1967) stated that the soil in medium-tight sand is C class soil and its territorial soil class according to TEC-2007 is Z3. Since the depth of the groundwater level is $10 \mathrm{~m}$ below surface, no liquefaction occurred during the earthquake. However, as the building is on alluvial soil, this increased the magnitude of the effects of the earthquake in the upper structure.

These data were used to develop a three-dimensional model of the building. For performance analysis, SAP2000 was used. The 3-D image from the program is presented in Fig. 20.

After modeling, the performance of the building was determined according to TEC-2007 norms. Figure 21 shows load-displacement (capacity) curves for both directions of the building in plan plane. In addition, Figs. 22 and 23 show individual damage measures of columns and beams comprising the load system. Even though this second case study building showed better performance than the first building, the global performance level in this building was found to be $\mathrm{CP}$ according to TEC-2007 criteria.
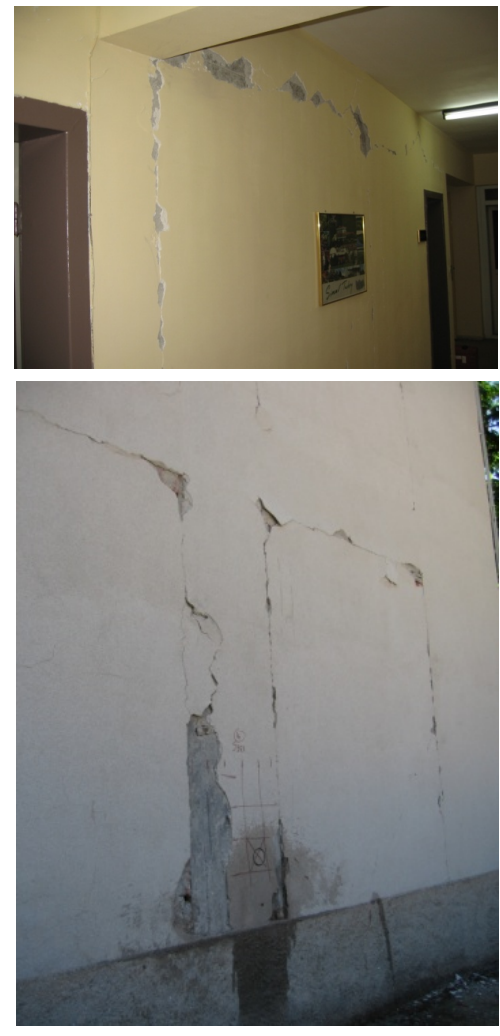

Fig. 19. Damage of filled wall.

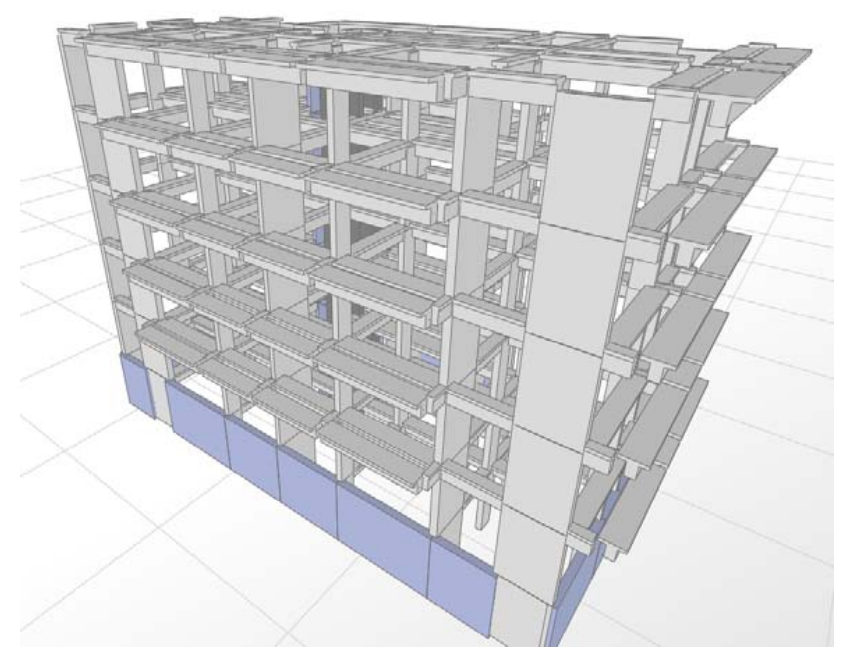

Fig. 20. Case study 2 (3-D structural model). 
Table 6. Compressive test results of the concrete specimens - case study 2 .

\begin{tabular}{|c|c|c|c|c|c|c|}
\hline Specimen No & $\mathrm{r} / \mathrm{h}$ & $\lambda=\mathrm{h} / \mathrm{r}$ & $\mathrm{P}(\mathrm{kN})$ & $\begin{array}{r}\mathrm{f}_{\lambda, d} \\
\text { P/A (MPa) }\end{array}$ & $\begin{array}{r}\mathrm{f}_{\varphi 15 / 30} \\
(\mathrm{MPa})\end{array}$ & $\begin{array}{r}\mathrm{f}_{15} \times 15 \times 15 \\
(\mathrm{MPa})\end{array}$ \\
\hline $\mathrm{N}_{1}$ & $93 / 93$ & 1.00 & 79 & 11.63 & 9.88 & 11.63 \\
\hline $\mathrm{N}_{2}$ & $93 / 93$ & 1.00 & 121 & 17.82 & 15.14 & 17.82 \\
\hline $\mathrm{N}_{3}$ & $93 / 93$ & 1.00 & 40 & 5.89 & 5.00 & 5.89 \\
\hline $\mathrm{N}_{4}$ & $93 / 93$ & 1.00 & 101 & 14.87 & 12.64 & 14.87 \\
\hline $\mathrm{N}_{5}$ & $93 / 93$ & 1.00 & 66 & 9.72 & 8.26 & 9.72 \\
\hline $\mathrm{N}_{6}$ & $93 / 93$ & 1.00 & 65 & 9.57 & 8.13 & 9.57 \\
\hline $\mathrm{N}_{7}$ & $93 / 93$ & 1.00 & 125 & 18.41 & 15.65 & 18.41 \\
\hline $\mathrm{N}_{8}$ & $93 / 93$ & 1.00 & 82 & 12.08 & 10.27 & 12.08 \\
\hline $\mathrm{N}_{9}$ & $93 / 93$ & 1.00 & 36 & 5.31 & 4.51 & 5.31 \\
\hline $\mathrm{N}_{10}$ & $93 / 93$ & 1.00 & 62 & 9.13 & 7.76 & 9.13 \\
\hline $\mathrm{N}_{11}$ & $93 / 93$ & 1.00 & 54 & 7.95 & 6.75 & 7.95 \\
\hline $\mathrm{N}_{12}$ & $93 / 93$ & 1.00 & 47 & 6.92 & 5.88 & 6.92 \\
\hline $\mathrm{N}_{13}$ & $93 / 93$ & 1.00 & 39 & 5.74 & 4.88 & 5.74 \\
\hline $\mathrm{N}_{14}$ & $93 / 93$ & 1.00 & 101 & 14.87 & 12.61 & 14.87 \\
\hline $\mathrm{N}_{15}$ & $93 / 93$ & 1.00 & 67 & 9.87 & 8.39 & 9.87 \\
\hline $\mathrm{N}_{16}$ & $93 / 93$ & 1.00 & 61 & 8.99 & 7.64 & 8.99 \\
\hline $\mathrm{N}_{17}$ & $93 / 93$ & 1.00 & 73 & 10.75 & 9.13 & 10.75 \\
\hline $\mathrm{N}_{18}$ & $93 / 93$ & 1.00 & 72 & 10.61 & 9.02 & 10.61 \\
\hline
\end{tabular}

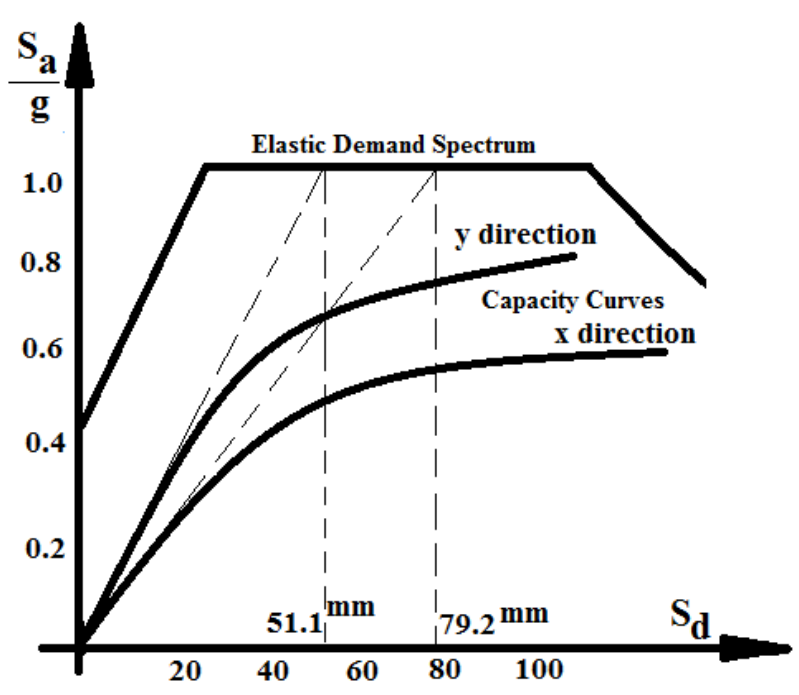

Fig. 21. Capacity curves at $\mathrm{x}$ and y directions for case study 2 .

\section{Results}

The present study summarized the examinations and field observations in the region following the earthquake and then calculated the performances of buildings surviving the earth- quake with medium damage according to TEC-2007 norms. The findings can be summarized as follows:

- It is clear that, even though the Kütahya-Simav earthquake of 19 May 2011 was of medium intensity, the damage observed in Simav center exceeded that predicted for this kind of earthquake. This situation reveals the discussed state of the current RC stock of Turkey. The results show that reinforced concrete buildings failed to meet expected performance standards in the Simav earthquake, due to structural defects, as reported previously in many articles about earthquakes in Turkey.

- The highest spectral acceleration recorded in the Simav earthquake was far less than that specified in the TEC2007 design standard (10\% probability of exceeding in $50 \mathrm{yr}$ ), which such buildings are expected to withstand. In addition, the duration of the earthquake was short, and therefore the damage sustained in the earthquake is striking.

- Both buildings examined in this study are in Simav center and located on Quaternary old alluvial soil. The soil is classed as clayey soil (SC), group is C in TEC-2007 and the territorial soil class is Z3. SPT number $\mathrm{N}_{30}$ generally ranged between 7 and 30 . The depth of the 
groundwater level was found to be 4.50 to $7.0 \mathrm{~m}$ in the first building and $10.0 \mathrm{~m}$ in the second building. Although the groundwater level is close to the surface, especially in the first building, no liquefaction occurred due to clay and aggregate in the soil. However, the soil type may vary even over very short distances. Therefore, it should be kept in mind that any difference in the depth of groundwater level may result in the risk of liquefaction.

- The upper structural damage in these two buildings shows that alluvial soils, which geotechnically are prone to liquefaction and have different subsidence and loadbearing capacity problems, also increase the effects of earthquakes and transfer a greater proportion of ground movements to buildings. Therefore, similar potential risks and geotechnical problems in present building deficiencies also will be present in buildings constructed in the future.

- In TEC-2007, the performance of existing RC building describes the sum of the cross-sectional damage limit. The section means column, beam and shear wall cross section at the ends. It is obvious that these investigated buildings do not have the satisfactory performance level given in TEC-2007, therefore these buildings must be strengthened from the foundation to the last story. However in this study, the authors only seek the superstructure performance. To obtain a more realistic model, detailed ground features should be reflected in the finite element analysis model for the cases where the deformation in the ground may affect the structural behavior.

- It was observed that rigidity and resistance is insufficient in RC buildings. This caused excessive shifts and heavy damage to filled walls in buildings even when the reinforced concrete frame did not sustain damage. In the earthquake which especially damaged the buildings projected before 1997, the filled wall had a significant role in the damage sustained by buildings. The existence of filled walls prevented damage to load system elements in many buildings or caused minor damage. In addition, irregularities such as soft stories or weak stories, attributed to filled walls, should be taken into consideration in modeling and calculation processes in addition to short column mechanism.

- Concrete mechanical properties are far from current building and earthquake codes. As seen in Fig. 24, the average core values of the related buildings are very low. In figure, variation of minimum concrete compressive strength to the TEC norms is also given.

- Data collection from the existing two RC buildings has been conducted according to the TEC-2007 Sect. 7 rules. Locations and numbers of longitudinal and transverse reinforcement elements of $20 \%$ of the columns and beams were determined using devices for reinforcement determining equipments. In some columns the cover of the reinforcement was scraped and the condition of the rebar only observed by the naked eye. The technical team had not taken any steel sample from the reinforced concrete members. For this reason, characteristic strength of used steel was accepted as $220 \mathrm{MPa}$ which is the lowest level given in TBC-500-2000 and TEC-2007.

- Medium level damage was seen in the two examined buildings. The presence of filled walls added significant rigidity to the building.

- The finding that beams and columns in the second building sustained less damage than those in first building can be explained by the seismic force-lateral load capacity ratio of the buildings.

- In the buildings examined according to TEC-2007 criteria, hinging is expected in the entirety of the columns in the first and second stories. In other stories, damage to column elements was expected to gradually decrease. However, hinging was not observed in the case study buildings.

- In contrast to field observations, both buildings are totally collapsible buildings according to the provisions of TEC-2007. Considering that the earthquake acceleration was slightly less than that specified in the regulations, combined with the presence of filled walls and the effect of attached buildings and other conditions in the regulation, the fact that the buildings were still standing indicates that the provisions of TEC-2007 are quite obligatory.

- The over strength coefficient of the 2nd building is 1.08 in the $\mathrm{x}$-axis and 1.3 in the $\mathrm{y}$-axis. TEC-2007 provides for the over strength coefficient as 1.5. This kind of coefficient calculation is not possible in the second building. Tragically, the capacity of the building is lower than the limit specified by TEC-2007.

\section{Discussion}

The omitting or canceling of infill walls is possible since they are architectural elements. It was observed that the wall layouts of the first and second stories of both buildings differed from the original architectural plans. TEC-2007 states that filled walls should be taken into consideration in the calculation of structural performance. However, the weight of an infill wall is regarded in determining the earthquake load affecting the building. The approach of the regulation to this issue has conservative characteristics. TEC-2007 and other regulations stress secondary effects of infill walls and express how they should be considered in structural modeling. 


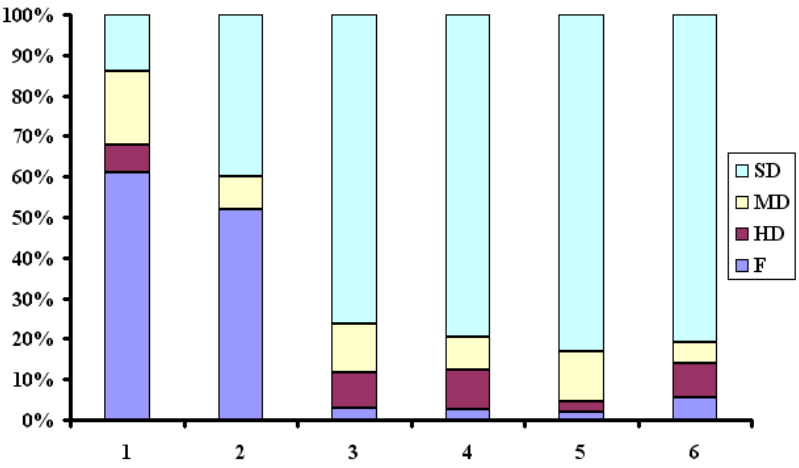

Fig. 22. Column cross-sectional damage.

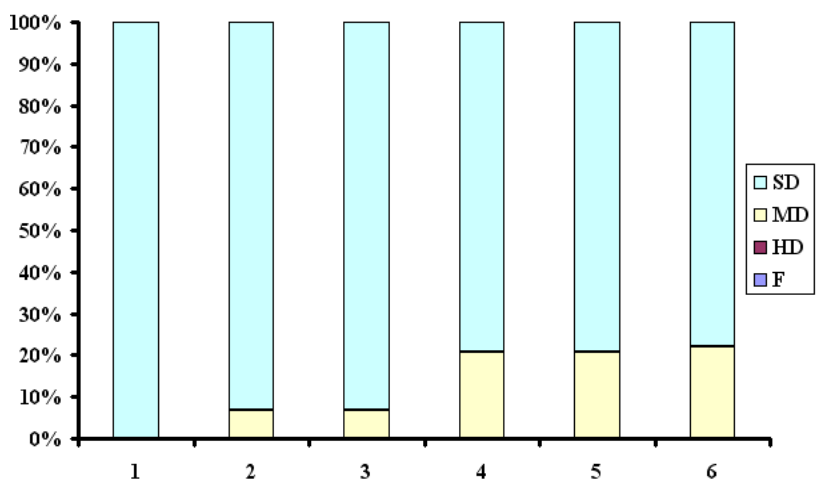

Fig. 23. Beam cross-sectional damage.

For example, for new buildings, the current European seismic codes Eurocode 8 assume that, if care has been taken to isolate the infill walls from the surrounding frames, the infill walls can be considered as "secondary elements". In addition, the irregularities that infill walls will create in a structure, such as soft stories or weak stories and short column behaviors that may occur in columns, should be taken into consideration in the performance calculations.

The basic criteria in the determination of structural performance are the levels of damage occurring in the column, beam and shear elements, which constitute the load-bearing system of the structure. The lower the displacement of the structure during an earthquake causes, the lower the damage occurring to the load system. Therefore, infill walls will positively affect structural performance.

From this point of view, it would not be wrong to say that adjacent building styles have a positive effect on structural performance. In modeling according to TEC-2007, the structures are planned separately. However, an important part of the performance of reinforced concrete buildings is the attachment to neighboring buildings (As example "case 2" of this study).

It has been established that the performance measures given for columns are very strict in TEC-2007. In their ex-

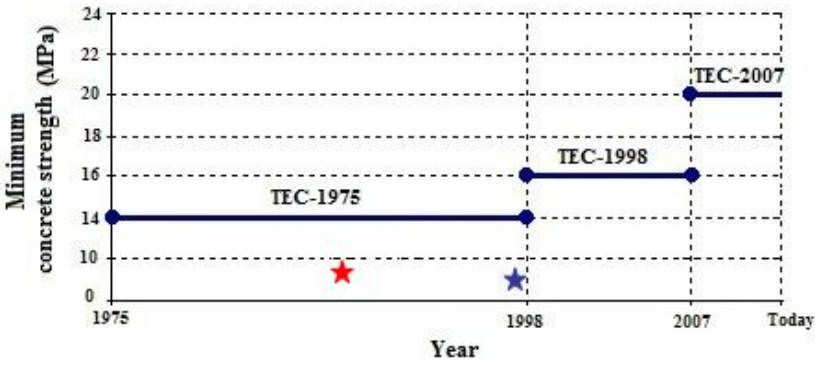

Fig. 24. Strength values of concrete used in the 1st (red star) and 2nd (blue star) building and the change of lower limit of concrete compressive strength according to regulations.

perimental/analytical studies, Acun and Sucuoğlu (2011) and Aydemir et al. (2011) compared various criteria of the regulations. They interpreted that TEC-2007 norms are very strict. An important part of the existing building stock in Turkey is stated to be non-compliant with the criteria of vertical and horizontal rebars given for columns in TEC-2007; therefore, the provisions of the regulation are highly strict for the columns not complying with the criteria.

Similarly, it is known that $L_{\mathrm{p}}=0.5 h$, which is the theoretical plastic hinge height given for columns, is very limited compared to experimentally obtained plastic hinge height data. Therefore, the regulation has punitive characteristics for columns from this point of view. In single mode static push analysis, the FEMA-356 standard related damage to elements directly to plastic hinge rotations. This eliminated the need for assumptions regarding plastic hinge length and facilitated element damage evaluation.

As beams are secondary elements compared to columns, it can be said that damage to beams does not have such a great effect on structural performance. However, according to TEC-2007, in order for a structure to provide IO performance level, the hinging rate in beams should be $10 \%$ or less. If this rate is higher than $10 \%$, the structure should be strengthened according to the using type. Similarly, for LS performance level, the advanced damage in beams should not exceed $30 \%$. According to this scenario, TEC-2007 states that buildings where columns are undamaged, but beams have some damage, are within the collapsing limits and should be strengthened. These conditions are also thought to be quite strict.

Considering the above-mentioned provisions, it is obvious that the significant proportion of the existing building stock in Turkey, which was constructed prior to TEC-1998, is non-compliant with current earthquake construction codes FEMA-356, and that leaving these buildings in their present state would be risky. However, when the Marmara and Düzce earthquakes of 1999 are examined, even though there were serious fatalities and material losses, only $6 \%$ of buildings within the total structure stock of that time completely collapsed or sustained serious damage (Tezcan et al., 2011). In 
this situation, there are significant differences between the criteria of regulation and the results of buildings that have experienced the test of a real earthquake.

\section{Conclusions}

In Turkey, most of the buildings built before 1998 code are far from achieving the desired seismic performance given in TEC-2007. The seismic evaluation case studies result confirmed prior expectations that the structural system considered to be typical of many Turkish buildings is inadequate for expected seismic demands. It is obvious that with only two case studies, clear data could not be given about Turkish reinforced concrete stock. However, it is clear that the buildings designed before the TEC-1998 seismic code and constructed without an effective control mechanism have similar structural deficiencies, and the same structural deficiencies cause the same structural damages to occur.

In addition to the negative view of the situation, there have been significant changes in Turkey due to the earthquake regulations of 1998 and 2007, and increased control mechanisms have ensured that structures built in the last 10 years incorporate earthquake-resistant features. However, a significant proportion of the existing buildings, which are thought to constitute $45 \%$ of RC buildings, were constructed before 1998 and were not subject to sufficiently tight controls; therefore, the earthquake performance of these structures, especially important, historical, and critical buildings, should be accurately re-evaluated as a matter of priority.

Acknowledgements. The authors offer their profound gratitude to the Selcuk University BAP and Necmettin Erbakan University BAP office for their financial support.

Edited by: M. E. Contadakis

Reviewed by: two anonymous referees

\section{References}

Acun, B. and Sucuoglu, H.: Evaluation of the performance limit states of RC columns in view of experimental observations, Tech. J. Turkish Chamber Civil Eng., 22, 5523-5542, 2011.

Adalier, K. and Aydıngün, O.: Structural engineering aspects of the June 27, 1998 Adana-Ceyhan (Turkey) earthquake, Eng. Struct., 23, 343-355, 2001.

AFAD: A Report on the 19 May 2011 Kütahya-Simav Earthquake, in collaboration with Earthquake Engineering Research Center (EERC) Middle East Technical University, Report No: METU/EERC 2011-02, Ankara, Turkey, June 2011.

Arslan, M. H.: An evaluation of effective design parameters on earthquake performance of RC buildings using neural networks, Eng. Struct., 32, 1888-1898, 2010.

Arslan, M. H. and Korkmaz, H. H.: What is to be learned from damage and failure of reinforced concrete structures during recent earthquakes in Turkey?, Eng. Failure Analy., 14, 1-22, 2007.
Aydemir, C., Kırcıl, M. S., Hancioglu, B., and Zorbozan, M.: Determination of flexural damage curvature capacity of RC columns, Tech. J. Turkish Chamber Civil Eng., 22, 5613-5642, 2011.

Celep, Z., Erken, A., Taskin, B., and Ilki, A.: Failures of masonry and concrete buildings during the March 8, 2010 Kovancilar and Palu (Elazığ) Earthquakes in Turkey, Eng. Failure Analy., 18, 868-889, 2011.

CEN, Eurocode 8: Design of structures for earthquake resistance, Part 3: Assessment and retrofitting of buildings, Brussels, 2005.

Çağatay, İ. H.: Experimental evaluation of buildings damaged in recent earthquakes in Turkey, Eng. Failure Analys., 12, 440-452, 2005.

Doğangün, A.: Performance of reinforced concrete buildings during the May 1, 2003 Bingöl Earthquake in Turkey, Eng. Struct., 26, 841-856, 2004.

FEMA-356: Prestandard and commentary for seismic rehabilitation of buildings, FEMA, 2000.

FEMA-440: Improvement of nonlinear static seismic analysis procedures, FEMA, 2005.

Inel, M., Ozmen, H. B., and Bilgin, H: Re-evaluation of building damage during recent earthquakes in Turkey, Eng. Struct., 30, 412-427, 2008.

Inel, M., Ozmen, H. B., Akyol, E., and Çayc1, B. T.: A Report on the 19 May 2011 Kütahya-Simav Earthquake and aftershocks, Denizli, Turkey, 2011.

Kaltakc1, M. Y., Arslan, M. H., Yılmaz, Ü. S., and Arslan, H. D.: A new approach on the strengthening of primary school buildings in Turkey: An application of external shear wall", Building Environ., 43, 983-990, 2008.

Kaplan, H., Yilmaz, S., Binici, H., and Çetinkaya, N.: May 1, 2003 Turkey-Bingöl earthquake: damage in reinforced concrete structures, Eng. Failure Analy., 11, 279-291, 2004.

Kaplan, H., Tama, Y. S., Y1lmaz, S., Kayhan, A. H., and Ün, H.: Simav earthquake constructional hazards preliminary research report, Denizli, Turkey, 2011.

Konak, N.: Simav surrounding geology and the evolution of its metamorphic rocks, Istanbul Geosci., 313-337, 1982.

SAP2000: V14. Computers and Structures, Inc., CSI Analysis Reference Manual for SAP2000, ETABS and SAFE, Computer and Structures, Inc., Berkley, California, 2010.

Saroğlu, F., Boray, A., and Emre, O.: Active faults of Turkey, Mineral Res. Explor. Inst. Turkey, Unpubl. Report, 8643, 394 pp. 1987.

Saroğlu, F., Emre, O., and Kuscu, I.: 1:1000000 Active Fault Map of Turkey, MTA, 1992.

TBC-500-2000: Turkish Standart Institute, Building code requirements for reinforced concrete, Ankara, Turkey, 2000.

Sengor, A. M. C., Goru, N., and Varoğlu, F.: Strike-slip faulting and related basin formation in zones of tectonic escape; Turkey as a case study, Strike-slip Deformation, Basin Formation and Sedimentation, Society of Economic Paleontologists and Mineralogists, Special Publication, 37, 1985.

Sezen, H., Whittaker, A. S., Elwood, K. J., and Mosalam, K. M.: Performance of reinforced concrete buildings during the August 17, 1999 Kocaeli, Turkey earthquake, and seismic design and construction practise in Turkey, Eng. Struct., 25, 103-114, 2003.

Tan, O., Tapırdamaz, M. C., and Yörük, A.: The earthquake catalogues for Turkey Turkish Journal of Earth Sciences, Turkish J. Earth Sci., 17, 405-418, 2008. 
Tama, Y. S.: Structural damages observed in state buildings after Simav/Turkey earthquake occurred on 19 May 2011, Nat. Hazards Earth Syst. Sci., 12, 2709-2718, doi:10.5194/nhess-122709-2012, 2012.

TEC-1998: Turkish Earthquake (Seismic) Code, Regulations on structures constructed in disaster regions, Ministry of Public Works And Settlement, Ankara, 1998.
TEC-2007: Turkish Earthquake (Seismic) Code, Regulations on structures constructed in disaster regions, Ministry of Public Works And Settlement, Ankara, 2007.

Terzaghi, K. and Peck, R. B.: Soil Mechanics in Engineering Practice, John Wiley and Sons, New York, 1967.

Tezcan, S., Bal E. İ., and Gülay, G.: P25 Scoring method for the vulnerability assessment of R/C buildings, J. Chinese Instit. Eng., 34, 769-781, 2011. 